Article

\title{
Urban Areas and Urban-Rural Contrasts under Climate Change: What Does the EURO-CORDEX Ensemble Tell Us?-Investigating near Surface Humidity in Berlin and Its Surroundings
}

\author{
Gaby S. Langendijk ${ }^{1,2, * \mathbb{D}}$, Diana Rechid ${ }^{1}$ and Daniela Jacob ${ }^{1,2}$ \\ 1 Climate Service Center Germany (GERICS), Helmholtz-Zentrum Geesthacht (HZG), Chilehaus, \\ Fischertwiete 1, 20095 Hamburg, Germany; diana.rechid@hzg.de (D.R.); daniela.jacob@hzg.de (D.J.) \\ 2 Faculty of Sustainability, Leuphana University of Lüneburg, Universitätsallee 1, 21335 Lüneburg, Germany \\ * Correspondence: gaby.langendijk@hzg.de
}

Received: 10 October 2019; Accepted: 18 November 2019; Published: 21 November 2019

check for updates

\begin{abstract}
Climate change will impact urban areas. Decision makers need useful climate information to adapt adequately. This research aims to improve understanding of changes in moisture and temperature projected under climate change in Berlin compared to its surroundings. Simulations for the Representative Concentration Pathway (RCP) 8.5 scenario from the European Coordinated Regional Climate Downscaling Experiment (EURO-CORDEX) $0.11^{\circ}$ are analyzed, showing a difference in moisture and temperature variables between Berlin and its surroundings. The running mean over 30 years shows a divergence throughout the twenty-first century for relative humidity between Berlin and its surroundings. Under this scenario, Berlin gets drier over time. The Mann-Kendall test quantifies a robust decreasing trend in relative humidity for the multi-model ensemble throughout the twenty-first century. The Mann-Whitney-Wilcoxon test for relative humidity indicates a robust climate change signal in Berlin. It is drier and warmer in Berlin compared to its surroundings for all months with the largest difference existing in summer. Additionally, the change in humidity for the period 2070-2099 compared to 1971-2000 is larger in the summer months. This study presents results to better understand near surface moisture change and related variables under long-term climate change in urban areas compared to their rural surroundings using a regional climate multi-model ensemble.
\end{abstract}

Keywords: urban climate change; urban-rural interactions; humidity; Berlin; regional climate modeling; EURO-CORDEX

\section{Introduction}

Climate change poses severe challenges to urban areas and climate change impacts will magnify throughout the century alongside rapid ongoing and projected urbanization [1-3]. To adequately face these climate-change-related challenges, urban decision makers require tailored climate information to develop mitigation and adaptation strategies to build the sustainable cities of tomorrow [4-6].

At the foundation of reliable science-driven climate information lies climate projections by climate models which can be used to understand and adapt to future climatic changes. Currently, most climate data and information produced by urban or climate models are either not scale compliant for cities, offer only a limited set of climatological parameters, or are unable to simulate urban-rural interactions. Regional climate models are a promising tool to bridge scales between global climate models and local scale urban models, simulating regional scale processes and urban-rural interactions under climate change. 
The Coordinated Regional Climate Downscaling Experiment (CORDEX) offers a state-of-the-art global framework for regional climate model (RCM) simulations and brings together around 30 regional climate modeling groups from across the globe [7-9]. Presently, only a limited sub-set of RCMs have developed a more complex representation of urban structures for their models and have conducted explicit studies on urban areas [10-12]. Due to limited available computing power, most of the detailed urban model projections with higher spatial resolutions $\left(100 \mathrm{~m}^{-3} \mathrm{~km}\right.$ grid size) simulate short time ranges, from a few days to a few years, and only focus on a sub-set of climatological variables. Often these sophisticated urban climate models simulate mainly meteorological phenomena based on temperature and/or heat budgets, such as the urban heat island effect (UHI) [11-16]. Existing urban modeling studies are able to represent and project the UHI fairly well for different case-study cities worldwide [11,12,15,17-19]. Several studies have indicated that urban areas have an influence on their surroundings and their local-to-regional climate, particularly for temperature, wind, and precipitation $[18,20]$.

It remains challenging to provide longer time-scale climate projections tailored to urban areas for a more diverse set of climatological phenomena [6]. Particularly, change in moisture, and its dependent variables such as specific humidity, relative humidity, and temperature, are not well understood. Observational studies have identified moisture differences between cities and their surroundings in past time periods around the world [21-30]. Some studies have quantified a drying in the city, the so-called urban dry island (UDI) effect (e.g., [31,32]). However, to our knowledge no studies have explicitly investigated changes in moisture in urban areas relative to their surroundings under climate change conditions using a regional climate multi-model ensemble.

Changes in moisture in urban areas under climate change could impact city sectors such as building structure, health, and biodiversity, resulting in a profound effect on the livability of cities. For instance, relative humidity is of direct importance to human heat stress and health [33-35]. Additionally, moisture levels can influence the sustainability of buildings by, for instance, altering the moist risks or endurance of building material $[36,37]$. Furthermore, humidity has an impact on vegetation growth, biodiversity, and ecosystem services in urban areas [38].

Despite its importance to living conditions, the impact of climate change on moisture in cities, as well as urban-rural moisture contrasts, remains under explored [39]. Enhanced understanding of these moisture phenomena and urban-rural interactions would improve climate information. This would enable informed adaptation decisions that influence the livability of cities under climate change [4-6]. In this context, the main objective of this research was to investigate changes in moisture and related variables under climate change conditions in the urban-rural context. Berlin and its surroundings were selected as the case study area. According to our knowledge, this study is the first of its kind to investigate whether the EURO-CORDEX multi-model ensemble captures urban-rural contrasts for moisture and related variables such as temperature in Berlin and its surroundings. In addition, the study explores the presence of a UDI and quantifies change in the urban-rural moisture contrast throughout the twenty-first century under climate change conditions. The research outcomes improve understanding of the opportunities and limitations of EURO-CORDEX data's applicability to urban areas and could inform further research on this topic.

\section{Experiments}

\subsection{Research Area}

To investigate humidity under climate change in urbanized areas, we selected Berlin and its surroundings. Berlin, the capital of Germany, is a large-scale city with around 3.6 million inhabitants covering approximately $891.1 \mathrm{~km}^{2}$ [40]. The city is located in-land in a relatively flat topography and is surrounded by predominantly forests and agricultural land. The size and geographical location of Berlin makes it a suitable case-study to investigate using regional climate model output data. 
The grid boxes of the EURO-CORDEX models are around $11 \mathrm{~km} \times 11 \mathrm{~km}\left(0.11^{\circ}\right)$, being together roughly $120 \mathrm{~km}^{2}$. Approximately seven grid boxes include an urban land-use type for Berlin. Some EURO-CORDEX models follow a fractional approach where the fluxes are calculated based on a mix of land-use types within one grid box. Other RCMs contain a dominant tile approach in which the fluxes are calculated based on the dominant land-use type within one grid box. This results in a different representation of the urban surface in the models. In this research, we considered Berlin per its administrative borders. Berlin was sliced out from the regional climate model output data through a geographically referenced weighted polygon of the administrative city boundaries (black polygon, Figure 1b). Because grid boxes and urban representation differ among the investigated models, this method provided a consistent data selection approach for Berlin across the model output data. The surroundings of Berlin were selected through a rectangular domain from approximately $140 \mathrm{~km}$ by $100 \mathrm{~km}$ located around the administrative boundaries of the city (black rectangle, Figure $1 \mathrm{~b}$ ). The land cover of the surroundings is roughly $50 \%$ agricultural and grass land, $36 \%$ forest, and $14 \%$ built-up areas and water bodies (Figure 1b) [41].

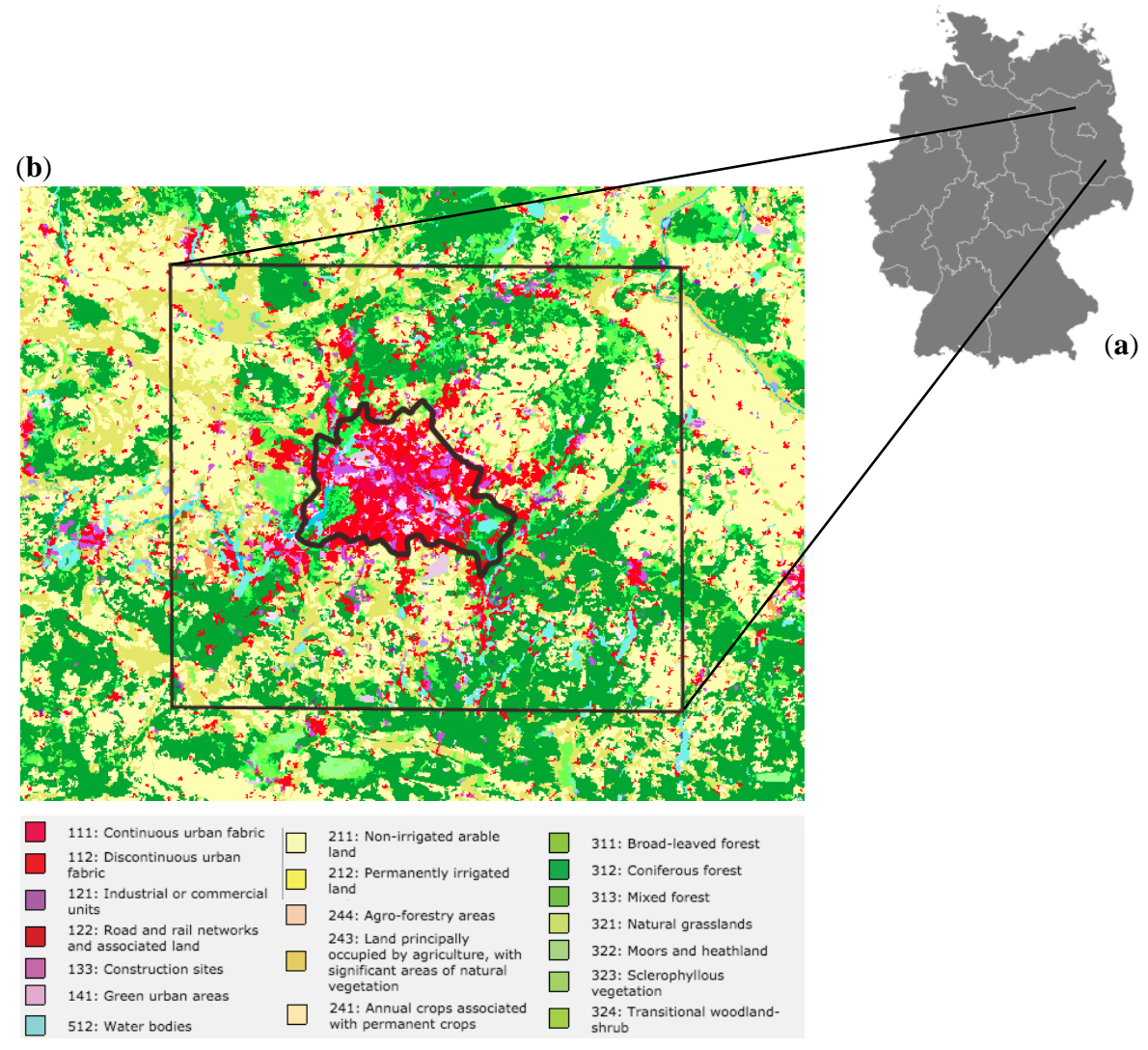

Figure 1. Research area. (a) Germany and (b) a land-cover map indicating Berlin's administrative boundaries (black polygon) and research domain including its surroundings (black rectangle). Land cover follows the CORINE land cover map [42].

\subsection{Data, Variables, and Climate Scenarios}

This research investigated regional climate model output data provided by the European CORDEX (EURO-CORDEX) using an approximately $12 \mathrm{~km}^{2}$ spatial resolution $\left(0.11^{\circ}\right)$ for the period 1970-2099 [7]. The data used for this study was obtained from the Earth System Grid Federation, CORDEX data node [43]. The multi-model ensemble considered for this study consists of ten model combinations, including several global circulation models (GCM), which are presented in Table 1. To understand how parameterization schemes of regional climate models represent urban areas, we conducted a short online survey within the EURO-CORDEX community and studied model documentation [44-52]. 
Table 1. Regional climate models and model combinations and their respective simulated variables which were investigated in this research (' $x$ ' means this variable was investigated). Legend: GCM, global circulation model; RCM, regional climate model; $\mathrm{RH}$, relative humidity; $\mathrm{SH}$, specific humidity; Tas, surface temperature at $2 \mathrm{~m}$ height; Tasmax, maximum surface temperature at $2 \mathrm{~m}$ height; Tasmin, minimum surface temperature at $2 \mathrm{~m}$ height.

\begin{tabular}{ccccc}
\hline $\begin{array}{c}\text { Driving Data } \\
\text { (GCM) }\end{array}$ & $\begin{array}{c}\text { Regional Model } \\
\text { (RCM) }\end{array}$ & $\begin{array}{c}\text { Regional } \\
\text { Modeling Group }\end{array}$ & $\begin{array}{c}\text { Humidity Variables } \\
\text { (RH and SH) }\end{array}$ & $\begin{array}{c}\text { Temperature } \\
\text { Variables (Tas, } \\
\text { Tasmax, Tasmin) }\end{array}$ \\
\hline EC-EARTH & RCA4 & SMHI & $\mathrm{x}$ & $\mathrm{x}$ \\
EC-EARTH & RACMO22E & KNMI & $\mathrm{x}$ & $\mathrm{x}$ \\
EC-EARTH & HIRHAM5 & DMI & $\mathrm{x}$ & $\mathrm{x}$ \\
CM5A-MR & WRF331F & IPSL & $\mathrm{x}$ & $\mathrm{x}$ \\
CM5A-MR & RCA4 & SMHI & $\mathrm{x}$ & $\mathrm{x}$ \\
HadGEM2 & RCA4 & SMHI & $\mathrm{x}$ & $\mathrm{x}$ \\
HadGEM2 & RACMO22E & KNMI & $\mathrm{x}$ & $\mathrm{x}$ \\
MPI-ESM-LR & REMO2009 & GERICS & $\mathrm{x}$ & $\mathrm{x}$ \\
MPI-ESM-LR & RCA4 & SMHI & $\mathrm{x}$ \\
EC-EARTH & CCLM4-8-17 & CLM community SH only & $\mathrm{x}$ \\
\hline
\end{tabular}

Relative humidity $(\mathrm{RH})$ and specific humidity $(\mathrm{SH})$ are the primary focus variables of this research as well as surface temperature at $2 \mathrm{~m}$ height (Tas) and minimum and maximum surface temperature at $2 \mathrm{~m}$ height (Tasmin and Tasmax, respectively). Relative humidity ( $\mathrm{RH}$ in $\%$ ) is generally calculated by the mass of the actual water vapor $\left(\mathrm{Mv}\right.$ in $\left.\mathrm{g} / \mathrm{m}^{3}\right)$ at a temperature divided by the mass of water vapor in saturation, depending on the temperature $\left(\mathrm{Mg}(\mathrm{T})\right.$ in $\left.\mathrm{g} / \mathrm{m}^{3}\right)$ (Equation (1)).

$$
\mathrm{RH}=\frac{M v}{M g(T)} \times 100 \%
$$

Observations were compared to the model output data to examine if both showed an urban-rural contrast for the variables, as well as to determine whether the magnitudes of these contrasts were similar. In situ measurements of individual meteorological stations in Berlin and its surroundings were obtained from the Climate Data Center (CDC) of the German Weather Service (DWD) [53]. These stations are selected and operated according to guidelines of the World Meteorological Organisation (WMO) as well as quality controlled to ensure homogeneity across the time series and between the different datasets. The particular datasets used for this research are based on hourly measurements and/or contain annual means calculated from the hourly data for each variable and observation station [54-57]. The measurement data from ten observation stations, of which six are in Berlin and four in the surroundings of Berlin, were compared to the multi-model mean between 1970 and 2017. The annual standard deviation for each model variable was calculated to investigate the climate variability. The period 1970 until 2017 was selected to cover the longest timespan available for the observational data as well as to comply with the historical model run period. The observation stations are spread across Berlin and located in different areas in its surroundings. The exact locations have been presented on a map in the Appendix A (Appendix A, Figure A1). Local effects influence measurements from observation stations [58]. Figure A1b shows the direct surroundings of the observation stations through Google Earth images to assist understanding of the local circumstances at each measurement station and to get a sense of its representativeness to the urban or rural context. RCM projections for the high emission, business-as-usual, Representative Concentration Pathway 8.5 (RCP 8.5), as defined by the Intergovernmental Panel on Climate Change (IPCC) [59], were selected for this study. This high-emission scenario has been chosen because it represents the most severe possible future under climate change among the available scenarios. We chose the worst-case scenario because it probably gives the most striking results for the investigated variables between Berlin and its surroundings as well as between the models. The RCP 8.5 scenario could be a stepping stone to investigation of other RCP scenarios. 


\subsection{Calculations and Statistics}

To investigate whether the EURO-CORDEX multi-model ensemble captures urban-rural contrasts for moisture, model output data and the differences between the regional climate models were investigated. Additionally, compliance between the models and the observations was explored. The annual mean of the in situ measurements was compared with the annual multi-model mean for Berlin, as well as for the surroundings, to analyze the differences and agreements between the models and the observations.

The running mean was calculated to explore whether a climate change trend is present in the climate output data for Berlin and its surroundings as well as to understand the differences between trends in urban and rural contexts. The running 30-year climatological mean was calculated from the annual mean for each variable and model combination for Berlin as well as for its surroundings. The multi-model running mean was calculated from the annual running mean of the individual model combinations [60]. The Mann-Kendall test (MK test) explores whether there is a monotonic trend and the direction of change of a time series (increasing/decreasing) [61,62]. Hence, the MK test was performed for each individual model's running mean for all the investigated variables. A robust result of a monotonic trend and direction of change for a variable was considered to have been obtained if more than $66 \%$ of the models showed similar, statistically significant ( $p$ value $<0.05$ ) outcomes for the test [63].

To further understand the climate change signal, the Mann-Whitney-Wilcoxon test (MWW-test) (or U-test) was applied to all investigated variables. The test investigates whether the future distribution (in this case 2070-2099) differs significantly for a variable compared to the distribution for the historic climate (in this case 1971-2000). A robust result was considered to have been obtained if more than $66 \%$ of the models showed similar results, implying a significant climate change signal for a variable [63]. One of the underlying assumptions for conducting a MWW-test is that the data is homogeneous of variances. To ensure this criterion was met the Levene test was conducted [64]. If the test outcome was not significant, meaning there was homogeneity of variances, the MWW-test was undertaken. Model combinations that could not pass the Levene test were left out of the climate change signal analysis for each variable.

Annual cycles of the variables were studied to understand changes per month and changes in annual cycles throughout the century as well as shifts in the seasons for humidity and temperature under climate change. The differences between Berlin and its surroundings were analyzed. Firstly, the annual cycle on a decadal basis between 1970 and 2100 was calculated for the investigated variables through calculating the annual multi-model mean averaged per decade. Secondly, a boxplot was created to understand the mean change when comparing 1971-2000 to 2070-2099, as well as the standard deviation and spread per month of the multi-model ensemble.

\subsection{Daily Cycle}

To further understand the urban-rural daily temperature contrast, underpinning the results for humidity, the hourly temperature data of the regional climate model REMO (version: MPI-M-ESM-LR_r1i1p1_REMO2009) was investigated $[49,50]$ in addition to the minimum and maximum temperature for all the EURO-CORDEX models.

The mean daily cycle was calculated over the period 1971-2000 for hourly data of the REMO model and compared to the observational mean of the hourly data over the same period for each day. The hourly data was obtained from the CDC of the DWD [65]. Based hereupon, for January, April, July, and October, the daily mean over the month was calculated to understand the daily cycle differences throughout the year. For Berlin as well as its surroundings the mean of the respective observation stations was considered in the analysis. Differences in the diurnal temperature cycle between Berlin and its surroundings were explored for the models and the observations to understand the urban-rural contrasts and whether these had been adequately simulated by the models. The mean daily minimum and maximum temperature for the period 1971-2000 in Berlin and for its surroundings 
were investigated for each EURO-CORDEX model for January, April, July, and October to understand whether the models showed comparable results to REMO for the daily cycle urban-rural contrast.

\section{Results}

The results section is divided into two main parts. The first part investigates how the EURO-CORDEX models represent urban areas in their models and whether differences are simulated for humidity and temperature between Berlin and its surroundings. To complement the first part, the model outcomes were compared with observations. The second part focuses on quantifying urban-rural contrasts for humidity and temperature variables under climate change conditions in the twenty-first century in Berlin and its surroundings.

\subsection{Models and Observations}

The running mean, calculated over 30 years for each EURO-CORDEX model and variable, was investigated to explore the general differences between the models and model combinations as well as the main differences between Berlin and its surroundings (Figure 2). Climate change trend analysis based on the running mean is discussed in the second part of the results section.

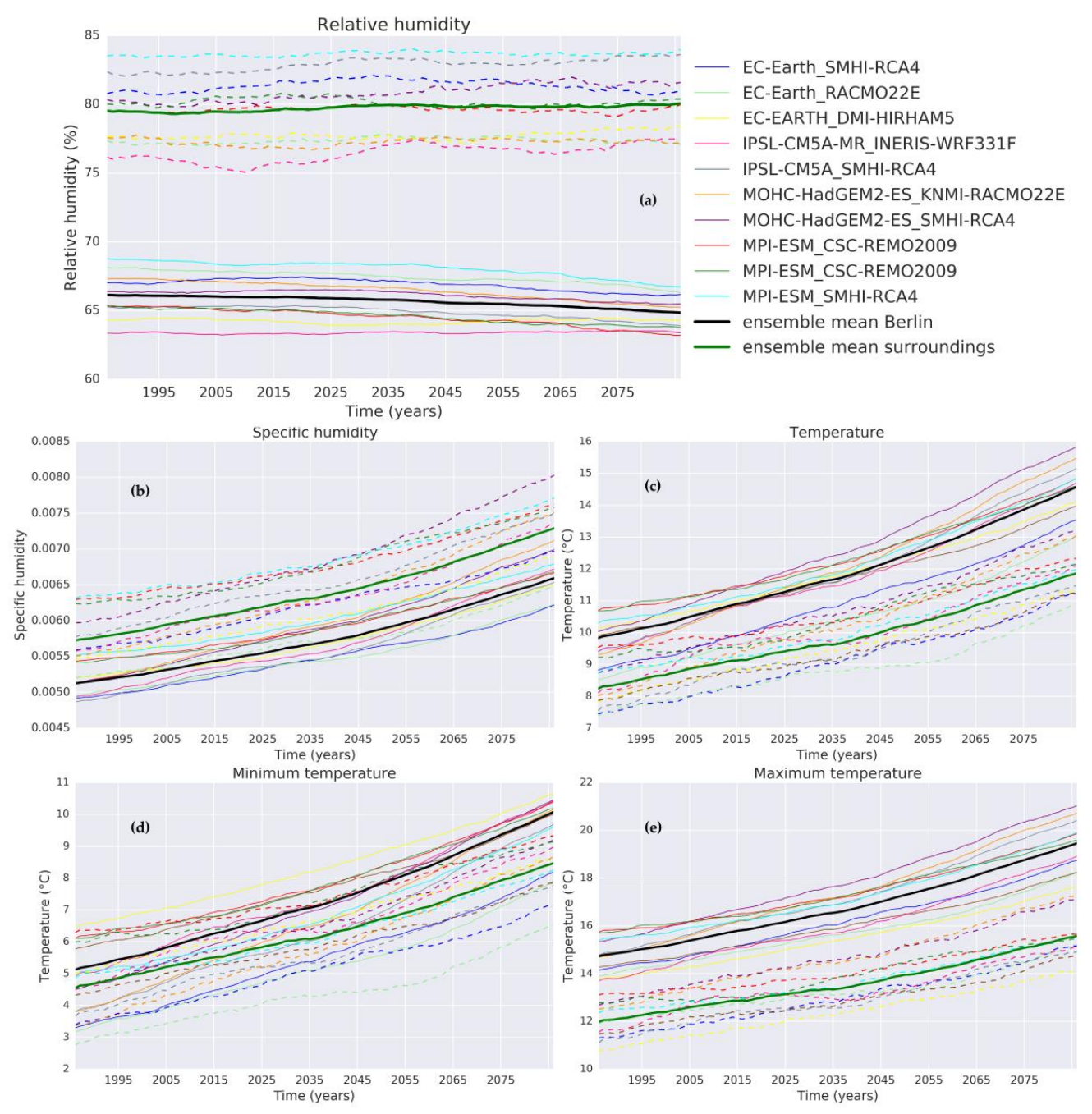

Figure 2. Running 30-year mean for 1970-2099 for individual European Coordinated Regional Climate Downscaling Experiment (EURO-CORDEX) models and the multi-model mean for (a) relative humidity, (b) specific humidity, (c) temperature, (d) minimum temperature, and (e) maximum temperature for Representative Concentration Pathway (RCP) 8.5, comparing Berlin (solid lines) and its surroundings (dashed lines). 
Figure 2 clearly demonstrates that all EURO-CORDEX models simulate distinct differences between Berlin and its surroundings for each variable. More specifically, the relative humidity and specific humidity are lower in Berlin than its surroundings, resulting in a water vapor deficit in Berlin compared to its surroundings (Figure 2a,b). Similarly, the temperatures are higher in Berlin than in its surroundings for all temperature variables considered in this study (Figure 2c-e). The EURO-CORDEX community survey (Appendix A: Table A1) and the studied model documentation indicate that the models represent urban areas through their land surface scheme and parameterizations, commonly by means of the 'bulk' scheme. Following this 'bulk' approach, sealed urban areas are represented as a rock surface, which is described in the models by a relatively high roughness length, high albedo, and no water storage capacities $[18,46,49,66]$. Model outcomes for Berlin show lower RH and higher temperature values than its surroundings (Figure 2). This general outcome can be explained as follows. In the models, large areas of Berlin are represented by a rock surface with a high surface runoff rate and a low capacity to store water. Hence, the evaporation rates are low and the atmospheric humidity levels decrease. Additionally, this leads to a low latent heat flux and a high sensible heat flux [10]. This results in higher temperatures and drier conditions simulated for Berlin compared to its surroundings.

The observations also show that Berlin is drier and warmer compared to its surroundings (Figure 3). There is a spread among the observations, particularly for $\mathrm{RH}$, temperature, and minimum temperature. The spread of the rural stations is considerably small compared to the stations in Berlin. The direct surroundings of all the rural observation stations are characterized by agricultural or grass fields (see Appendix A, Figure A1b). This similar land-use type explains the relatively small spread among the observational stations in rural areas. In Berlin, the spread between the stations is larger. The stations are located in different areas of the city, near (former) airports (Tegel and Tempelhof), green spaces (Dahlem), or roads and buildings (Ostkreuz, Marzahn, and Alexanderplatz) (see Appendix A, Figure A1b). The direct surroundings of observational stations have a profound influence on their measurements [58]. The observation station 'Alexanderplatz' is located in the city center of Berlin and is surrounded by compact buildings and an almost fully sealed surface. This station shows the highest temperature values (Figure 3b), which can be explained by the combined influence of its direct surroundings and its central location, which is where the city is at its hottest. The measurement values for RH and temperature of the stations 'Tegel' and 'Tempelhof', which are both near (former) airports, are similar. Trees and green areas can have a cooling effect in the city. 'Dahlem' is slightly cooler and more humid than the other stations because it is located near a green space. The colors of Figure 3 reflect the urban gradient, respectively showing the darkest red colors for the stations located in the inner city and lighter orange-yellow colors for sub-urban observation stations.

Comparing the model outcomes with the observations, similar generic outcomes can be seen to arise for the studied variables. Berlin is drier and warmer compared to its surroundings. Figure 3a shows that the multi-model mean simulates the RH annual mean by a slightly lower amount, i.e., by $3-10 \%$, than the observations indicate for Berlin. The models slightly overestimate, i.e., by $0-4 \%$, the relative humidity for the surroundings. This leads to a total overestimation by the models of the water vapor deficit in Berlin compared to its surroundings of around 3-14\%. The model spread is presented in the Appendix A (Figure A2). The models are centered around the multi-model mean and do not show a distinct exception for one or a few models. The standard deviation (Appendix A, Table A3) for Berlin is lower than $1 \%$ for each model and is between $1.5 \%$ and $2.5 \%$ for the surroundings. To summarize, the models are able to capture the rural-urban relative humidity contrast, with a dry overestimation in Berlin. This modeled water vapor deficit might be an effect of the urban parameterization scheme that results in low evaporation rates due to an overestimation of sealed rock surfaces compared to the actual urban surface with green spaces [10]. This leads to an increased drying effect in the model simulations compared to the observations. The observational station 'Alexanderplatz' in Berlin corresponds most correctly to the multi-model mean for RH (Figure 3a) and to a lesser extent for temperature (Figure 3b), which is in contrast to the other stations further away from the city center. The observation station 'Alexanderplatz', in the city center, is surrounded by 
compact buildings and an almost fully sealed surface (see Appendix A, Figure A1). This hints that the simple urban 'bulk' scheme in RCMs could represent sealed, central urban areas quite adequately with respect to climatological annual mean values. Nevertheless (sub-) urban areas with vegetated spaces remain more challenging to simulate correctly by regional climate models on the $0.11^{\circ}$ spatial scale.

For the mean annual temperature the models simulate temperature change over the past time period in a similar fashion to the observations, simulating namely an approximate increase of around 1.2-1.5 ${ }^{\circ} \mathrm{C}$ between 1970 and 2017 (Figure $3 \mathrm{~b}-\mathrm{d}$ ). The temperature difference between Berlin and its surroundings is overestimated by the models with a $\sim 2{ }^{\circ} \mathrm{C}$ difference between the two multi-model means compared to a $\sim{ }^{\circ} \mathrm{C}$ difference for the observations. This is mainly due to an underestimation of the temperature in the surroundings by the models (Figure $3 b$ ).

The standard deviation for the temperature variables calculated over the annual mean for each model is $<1^{\circ} \mathrm{C}$ in Berlin and between $0.5^{\circ} \mathrm{C}$ and $1.5^{\circ} \mathrm{C}$ for its surroundings (Appendix A, Table A3). The climate variability is low because it was calculated on an annual basis for a relatively small domain. The model spread (Appendix A, Figure A2) for the temperature variables is approximately $3{ }^{\circ} \mathrm{C}$ in Berlin and $\sim 4{ }^{\circ} \mathrm{C}$ for its surroundings. The global climate models driving RCMs largely affect the results for the temperature variables, particularly for CM5A-MR, HADGEM2, and MPI-ESM. Generally, the models capture the urban-rural contrast for temperature in a similar fashion as the observations, with a slight underestimation of the temperature in the surroundings. The models simulate the temperature trend in a comparable manner to the observations. This is expected to persist for future projections. The relative humidity trend is largely dependent on the temperature trend and therefore expected to be projected adequately by the models.

The annual maximum and annual minimum temperature show opposite urban-rural contrasts for Berlin and its surroundings when comparing the multi-model means with the respective observations (Figure $3 c, d$ ). The simulated difference in the maximum temperature between Berlin and its surroundings is larger than the simulated difference in the minimum temperature between both areas. By contrast, the observations show a smaller difference between the maximum temperature and the minimum temperature when comparing Berlin and its surroundings. This suggests that the models possibly do not capture the temperature difference correctly for the nighttime between Berlin and its surroundings. According to previous studies, the largest temperature difference between the urban and rural areas, the largest UHI, is expected during the night. In winter, the temperature difference between Berlin and its surroundings is expected to be smaller compared to other seasons $[67,68]$.

Based on the results presented in Figure $3 c, d$, there is a need to further understand whether the nighttime and daytime temperature differences between Berlin and its surroundings are adequately simulated by the regional climate models. The EURO-CORDEX community survey (Appendix A, Table A1) indicates that all RCMs represent urban areas in a similar fashion through a 'bulk' parameterization scheme. Hence, each model could be taken as a representative example for the other models. In this case, the REMO model was selected to further investigate the daily cycle because hourly data was directly available. The REMO hourly historic model mean on a daily basis between 1971 and 2000 for January, April, July, and October was compared to the equivalently calculated observational mean averaged over the observational stations in and outside Berlin. The diurnal cycle of the observations shows a daytime temperature maximum and nighttime minimum for both Berlin and its surroundings (Figure 4). Generally, it is during nighttime that the largest difference in temperature between Berlin and its surroundings occurs. For most months the modeled diurnal temperature cycles show a similar curve to the observations. Nonetheless, REMO simulates the largest temperature difference between Berlin and its surroundings during the daytime instead of the nighttime, opposing the observations and leading to an underestimation of the nighttime urban-rural temperature difference (Figure 4). 

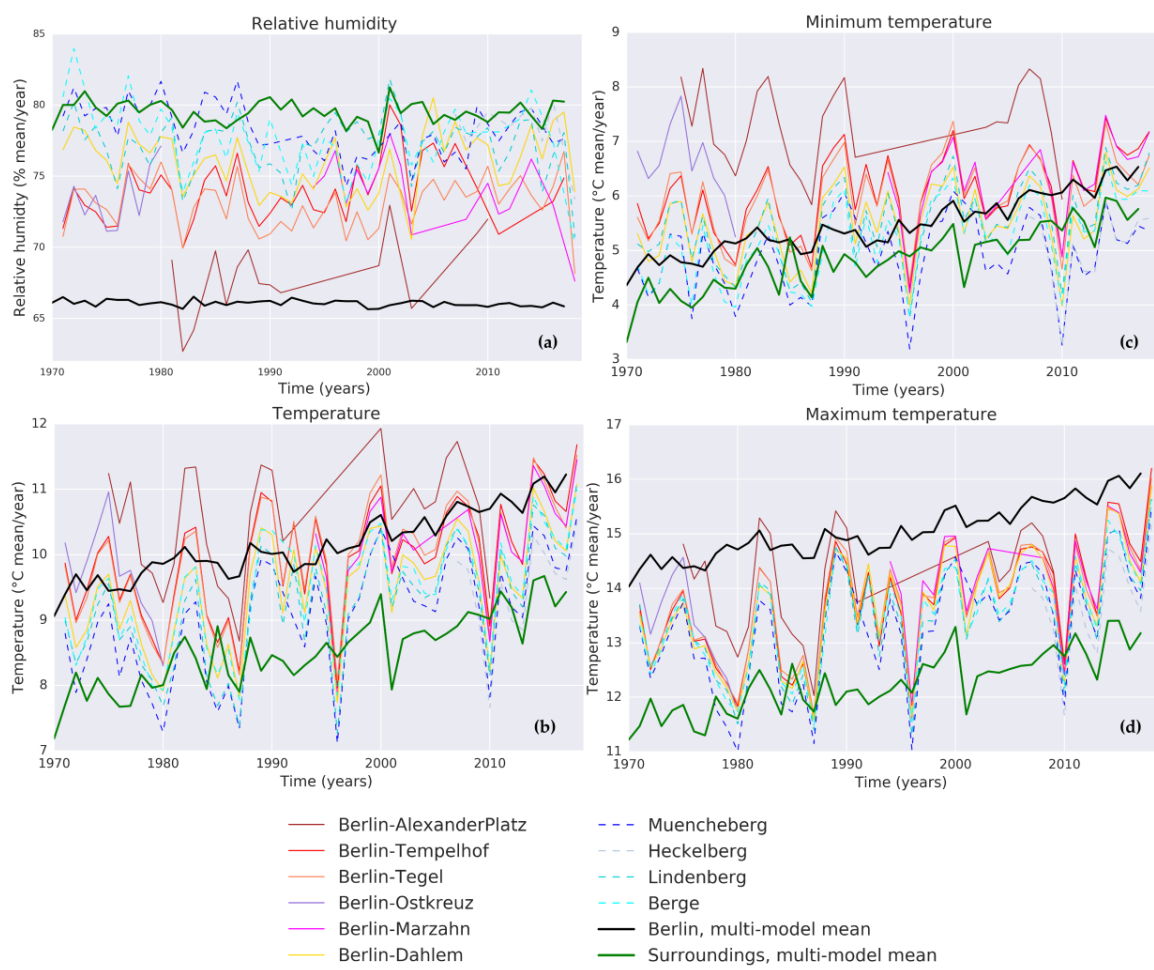

Figure 3. EURO-CORDEX multi-model annual mean compared to observation station data annual mean in Berlin and its surroundings for (a) relative humidity, (b) temperature, (c) minimum temperature, and (d) maximum temperature for 1970-2017.
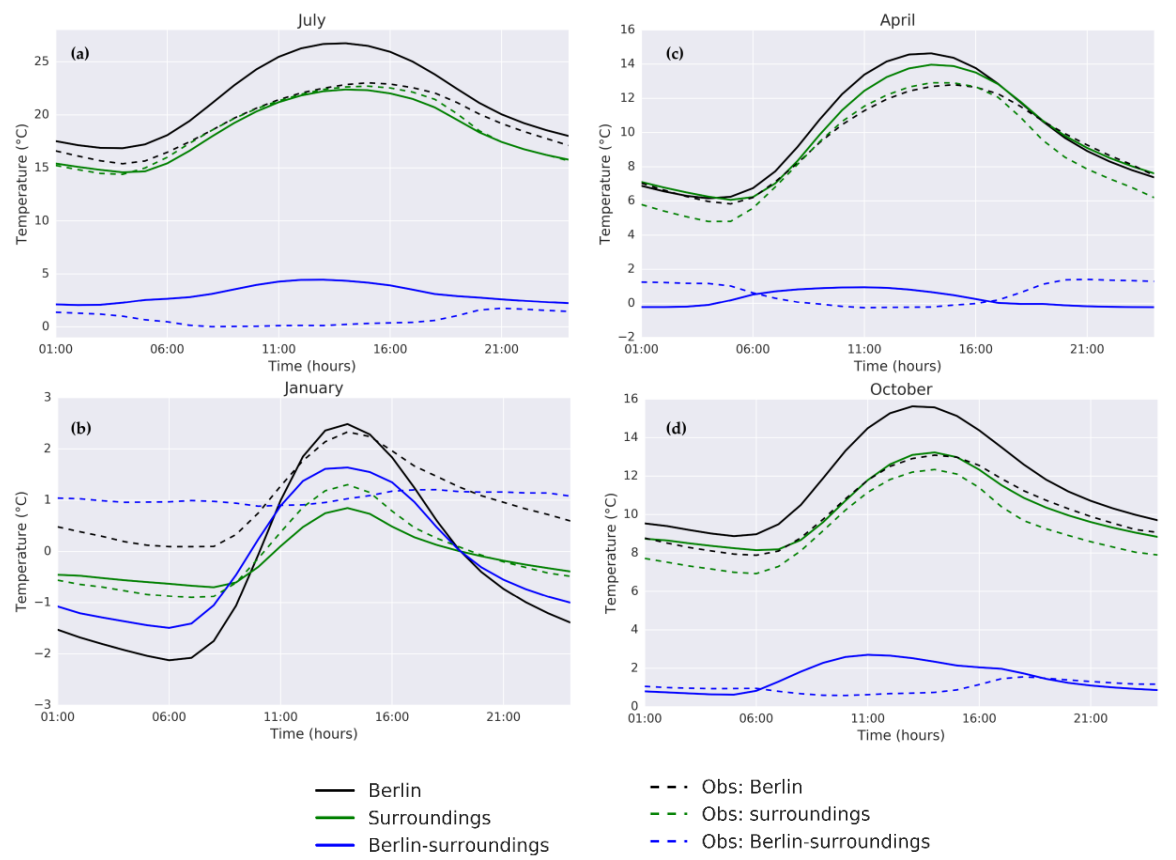

Figure 4. Temperature diurnal cycle. Hourly average between 1971-2000 for the monthly mean of (a) July, (b) January, (c) April, and (d) October. The hourly mean of regional climate model REMO (solid lines) is compared to the observational data (dashed lines) for Berlin (black) and its surroundings (green) as well as the hourly mean of the surroundings subtracted from the hourly mean of Berlin (blue).

During January the urban diurnal cycle is exacerbated, with a slightly stronger warming during the day and generally a stronger cooling at night. This is possibly due to long winter nights and short 
days with limited incoming solar radiation to warm up the urban surface and limited heat storage capacity. In reality, urban areas generally warm up faster than their surroundings and the heat is stored during the day and slowly released at night, leading to a larger temperature difference between a city and its surroundings at nighttime. This is in line with the observational diurnal cycles displayed in Figure 4. Conceivably, as a result of the 'bulk' parameterization scheme, the model is unable to trap the energy adsorbed during the day in the street canyons as heat is only stored in the surface layer with minimal thickness and no heat exchange between city elements is parameterized in the scheme. Additionally, anthropogenic heat is not considered explicitly, further limiting the nocturnal cooling potential of the surface and low atmosphere. Consequently, the model results show a stronger temperature difference between Berlin and its surroundings during daytime, misrepresenting the actual urban-rural largest temperature difference at night measured by the observations.

Similarly to REMO, the other EURO-CORDEX models investigated contain a 'bulk' scheme for urban areas. In this light, REMO can be seen to be representative of the other models and similar results may be expected. To validate the latter, an additional analysis investigates the daily minimum and maximum temperature for each model, comparing Berlin to its surroundings. According to previous studies, the UHI should be larger at night than during the day [67]. The results of the analysis are presented in Figure 5. Generally, the models do not show the expected outcome. The difference between the minimum temperature in Berlin (urbmin) and the minimum temperature in its surroundings (surrmin) is generally smaller (and in January even reversed) than the difference between the maximum temperature in Berlin (urbmax) compared to the maximum temperature in its surroundings (surrmax). The results for the EURO-CORDEX models are comparable to the results found for REMO. In summary, all EURO-CORDEX models simulate the UHI. However, the models do not simulate the timing of the UHI correctly. The temperature difference between Berlin and its surroundings peaks during the daytime instead of the nighttime.

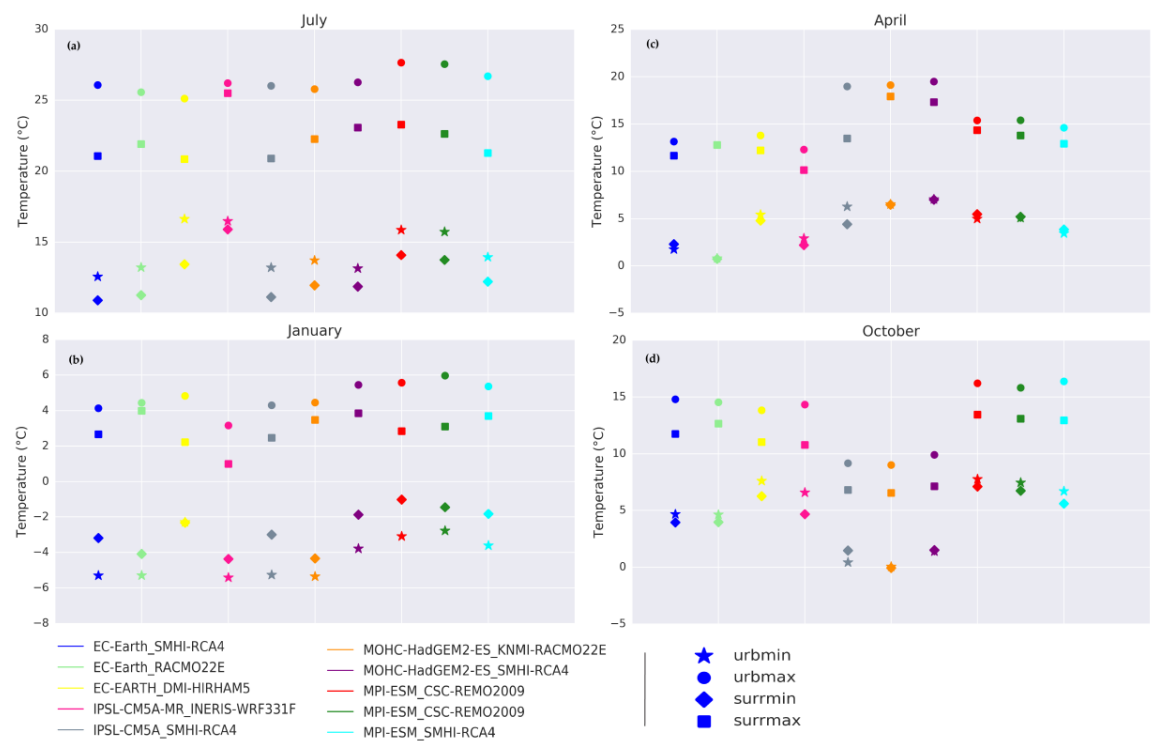

Figure 5. Temperature minimum and maximum for Berlin (urbmin/urbmax) and its surroundings (surrmin/surrmax) for the ten-model combination from the EURO-CORDEX multi-model ensemble. Daily average between 1971-2000 for the monthly mean of (a) July, (b) January, (c) April, and (d) October.

\subsection{Humidity under Climate Change}

As mentioned in the first part of the results section, the models generally indicate a water vapor deficit in Berlin, and it is on the whole warmer in Berlin compared to its surroundings throughout the twenty-first century (Figure 2). With respect to the 30 years running mean, specific humidity and temperatures increase throughout the century, both in Berlin and in its surroundings. For specific 
humidity, the difference in the multi-model mean between Berlin and its surroundings is constant over time. The temperature difference between Berlin and its surroundings is enlarged during the twenty-first century and is particularly characterized by a stronger warming in Berlin. Relative humidity is directly related to changes in temperature and specific humidity. The temperature increase is larger in Berlin throughout the twenty-first century, causing a decrease in $\mathrm{RH}$ in Berlin and a slight RH increase in its surroundings (Figure 2a). Urban areas retain heat better than their rural surroundings. The model results show that this urban heat island effect is likely to be amplified under rising temperatures and climate change conditions. The urban-rural diverging pattern for relative humidity was further analyzed with an MK test. The outcomes of the MK test show a robust result for Berlin, with $78 \%$ of the assessed models agreeing on a significant decreasing monotonic trend in Berlin for relative humidity throughout the century. For the surroundings the model agreement of a significant increasing monotonic trend is only $50 \%$ across the models and therefore not robust. For specific humidity, temperature, and minimum and maximum temperature the MK test shows $100 \%$ model agreement of a significant increasing trend for Berlin as well as for its surroundings (Appendix A, Table A2).

To enhance understanding of the climate change signal for the studied variables in Berlin and its surroundings, an MWW test was conducted. The MWW test outcome for relative humidity indicates, for the seven models that passed the Levene test, $71 \%$ of the models agree that the future distribution (2070-2099) is different from the historical distribution (1971-2000). In other words, the climate change signal in Berlin is robust for relative humidity. Thus, RH would decrease in Berlin under RCP 8.5 climate change conditions in the twenty-first century. For the surroundings, only $25 \%$ of the model combinations (eight out of nine passed the Levene test) show a different distribution in the future for relative humidity. Hence, the climate change signal for $\mathrm{RH}$ is not robust for the surroundings of Berlin (Appendix A, Table A2). The GCM CM5A-* driven model combinations show a different result for RH than the other model families. The RH decrease in Berlin is not significant for the CM5A-* family and the increase in RH in Berlin's surroundings shows significant results for the MWW test.

To gain insight into the change in the annual cycle under projected climate change in Berlin and its surroundings, the monthly multi-model mean on a decadal basis between 1970 and 2100 was investigated for each variable (Figure 6).

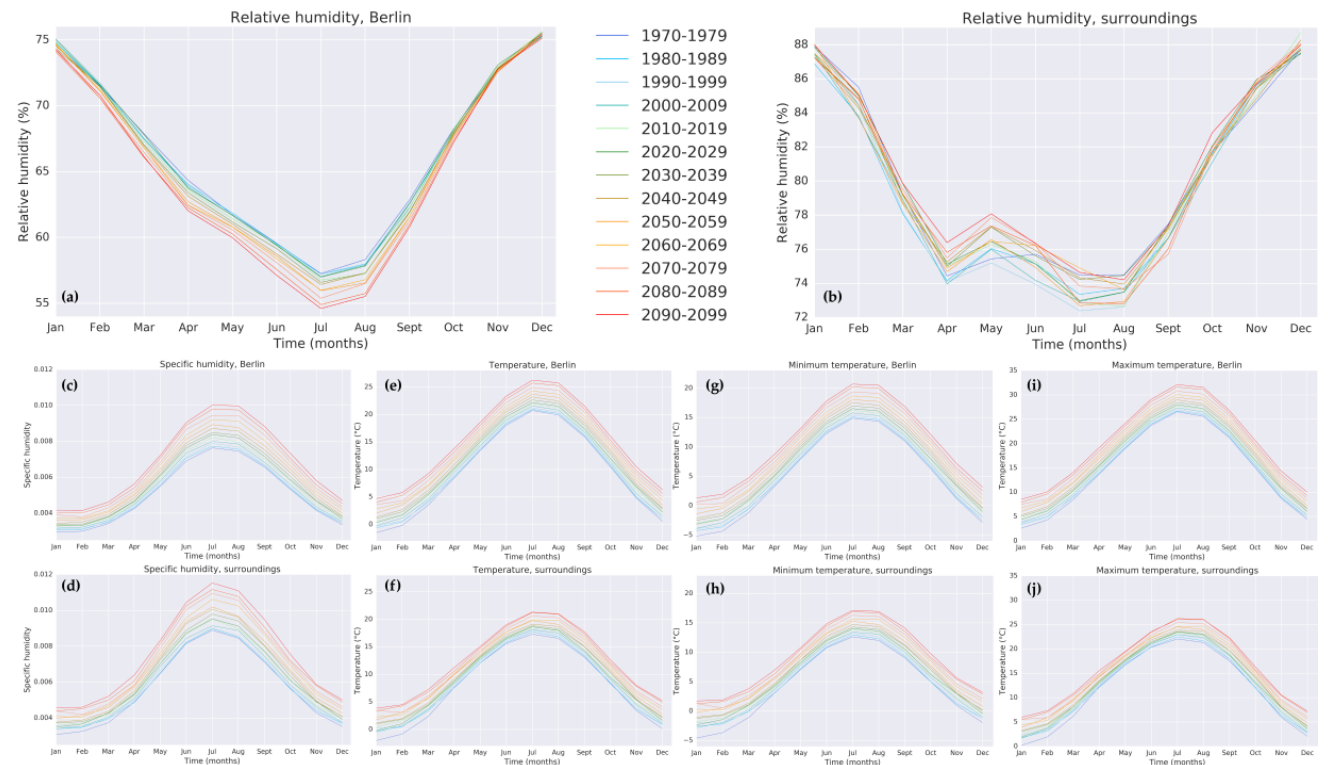

Figure 6. Decadal annual mean cycle for the period 1970-2100 of the EURO-CORDEX multi-model ensemble for RCP 8.5 and for Berlin and its surroundings. The figure shows the outcomes for the different variables: $\mathrm{RH}(\mathbf{a} / \mathbf{b}), \mathrm{SH}(\mathbf{c} / \mathbf{d})$, temperature $(\mathbf{e} / \mathbf{f})$, minimum temperature $(\mathbf{g} / \mathbf{h})$, and maximum temperature $(\mathbf{i} / \mathbf{j})$. 
Figure 2 shows that Berlin would get consistently drier (lower RH) than its surroundings throughout the year for each decade, particularly in the summer months (Figure 6a). The strongest RH change would occur in Berlin in the summer months, with an RH decrease of up to 6\% in 2090-2100 compared to 1970-1980 in contrast to hardly any change during the winter months. The up to $6 \%$ decrease in relative humidity $(\mathrm{RH})$ in Berlin contrasts with an average $\mathrm{RH}$ of about $66 \%$ projected by the RCMs (Figure 2a) and an average of about $73 \%$ RH measured by suburban stations and $68 \%$ RH by the inner-city station (Figure 3a). In addition, the $6 \%$ projected decrease in RH is comparable to the model spread of $4-5 \%$ (Figure 2a). Climate change has its strongest effect on the RH annual cycle in the summer months. This stronger change pattern in the summer months is also visible for specific humidity throughout the decades and to a lesser extent for temperature, underpinning the RH results. The strong change in the summer months can be explained by the increase in incoming solar radiation in the summer compared to winter, resulting in higher summer temperatures $[69,70]$. This increase in temperature exacerbates the air moisture deficit in summer, leading to a stronger drying effect in the urban areas in the summer months. An increase in relative humidity in the surroundings of Berlin is visible in May and to a lesser extent in June throughout the twenty-first century. This could be explained by low evaporation, predominantly cloudy skies, and dormant vegetation resulting in increased soil moisture with minimal fluctuations in winter. In spring, around April-May, increased vegetation growth removes moisture from the soil through intensive evapotranspiration, increasing $\mathrm{RH}$ in the atmosphere [70,71].

Figure 7 improves the understanding of the mean monthly change for each variable under climate change conditions, comparing 1971-2000 to 2070-2099. It uses box and whisker plots.
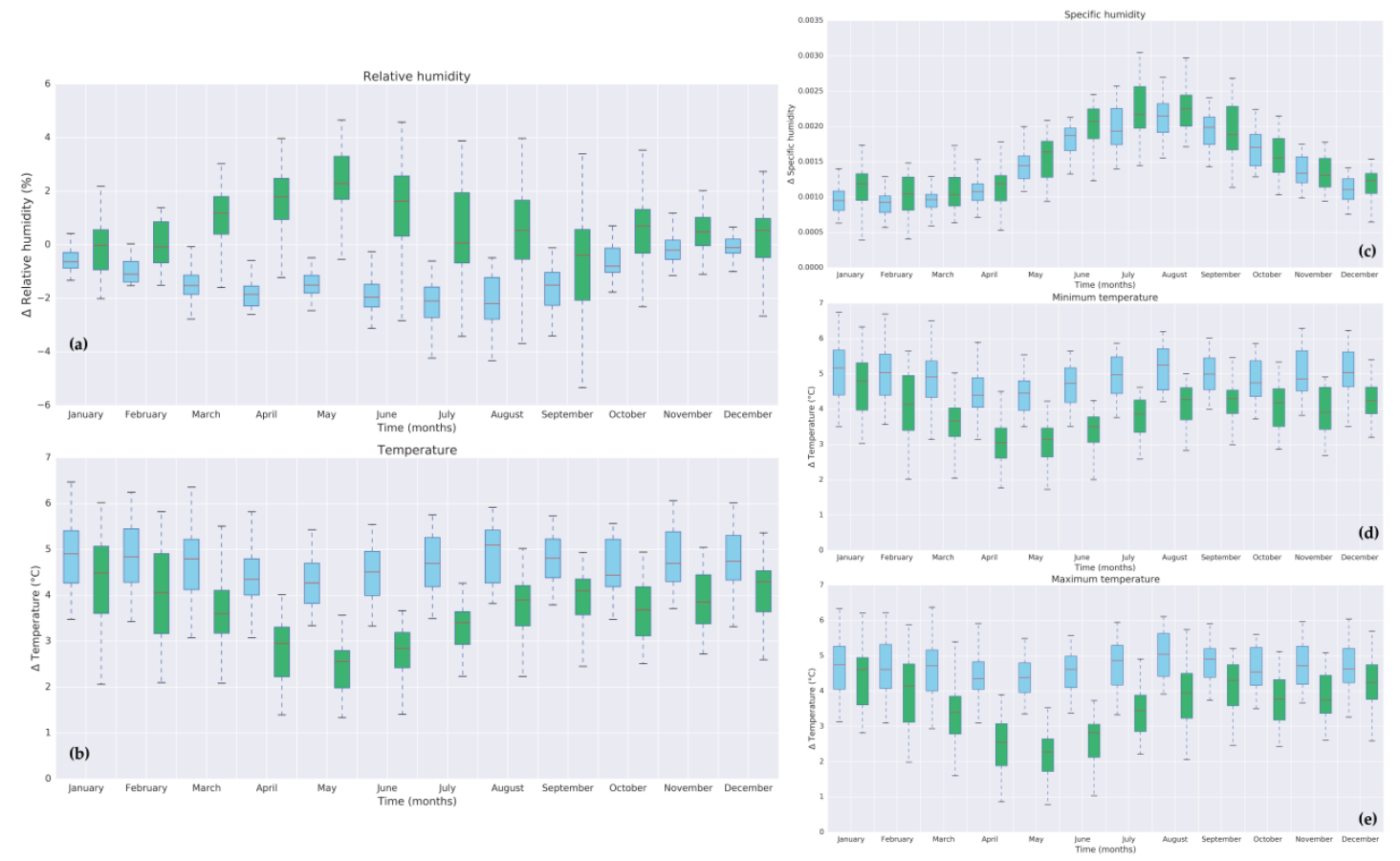

Figure 7. Mean monthly change for each variable under climate change conditions, comparing 1971-2000 to 2070-2099 for Berlin (grey-blue) and its surroundings (green) for (a) RH, (b) temperature, (c) $\mathrm{SH}$, (d) minimum temperature, and (e) maximum temperature for RCP 8.5. The multi-model median (red line), quartiles (Q1: 25\% and Q3: 75\%) and whiskers, including interquartile range (IQR) $(1.5 \times$ IQR $(\mathrm{IQR}=\mathrm{Q} 3-\mathrm{Q} 1))$ indicate the model spread.

In agreement with previous results, Figure 7 shows the strongest RH decrease by the end of the century in the summer months in Berlin of around $2 \%$, in contrast to hardly any change during the winter months. It shows a $2 \%$ increase in relative humidity for the surroundings in spring, which could 
be a result of the increase in evaporation as mentioned above. The biggest spread among the RCMs occurs in the surroundings and is generally slightly stronger at the end of summer (August-September). This could be due to differences in the available soil moisture in Berlin's surroundings. Because of increased evapotranspiration and decreased precipitation, the soil moisture is expected to be lower in the summer months. During the end of summer and fall the soil moisture recharge phase starts because harvest reduces the biomass and precipitation increases [70,71]. August and September are just on the verge of this phase transition, leading to potentially higher model uncertainties in relative humidity in the surroundings of Berlin.

With respect to temperature, the change between 1971-2000 and 2070-2099 would be around $4-5{ }^{\circ} \mathrm{C}$ in Berlin, with a slightly lower increase in spring (Figure 7). For the surroundings this change would be around $2-3{ }^{\circ} \mathrm{C}$ in spring and $3-4.5^{\circ} \mathrm{C}$ in the other months. Minimum and maximum temperature would follow a similar monthly change pattern. However, the minimum temperature change would increase slightly more than the maximum temperature, especially in spring and summer, with a difference of around $0.0-0.5^{\circ} \mathrm{C}$ for Berlin and around $0.0-0.7^{\circ} \mathrm{C}$ for its surroundings. The model spread is around $2{ }^{\circ} \mathrm{C}$ for all temperature variables in Berlin and its surroundings, except for the minimum temperature in the surroundings, which shows a $4-5{ }^{\circ} \mathrm{C}$ difference between the models (Figure 2c-e).

In summary, according to the EURO-CORDEX multi-model ensemble data for the RCP 8.5 scenario, Berlin is getting drier and faces a larger temperature increase than its surroundings by the end of the century under climate change conditions, especially in summer.

\section{Discussion}

All ten EURO-CORDEX model combinations showed a clear difference for humidity and related variables between Berlin and its surroundings. Several previous studies have also demonstrated a temperature difference between an urban area and its surroundings simulated by one or several EURO-CORDEX models (e.g., [10,20,72]). Hence, to our knowledge, this is the first study to take into consideration the EURO-CORDEX multi-model ensemble when analyzing humidity variables for Berlin and its surroundings. Only this approach enables us to derive information on potential future moisture changes in urban areas compared to their surroundings under climate change conditions.

Previous observational studies have investigated moisture differences between a city and its surroundings for past time periods. However, the main focus of many of these studies has been the diurnal cycle and these studies have been based on observational records only. These studies considered a wide range of different methods to analyze moisture, e.g., wet bulb temperature, specific humidity, and water vapor pressure. Throughout the world, in many cities a moisture deficit has been predominantly found (Cairo: 21, Chicago: 22, Christchurch: 23, Edmonton: 24, Lodz: 25, Mexico City: 26, Moscow: 31), but nevertheless urban moisture excess has also been identified primarily in others (Belgrade: 27, Krefeld: 28, London: 29, Szeged: 30). Some cities have shown a daytime urban moisture deficit, mainly because of reduced evapotranspiration and better turbulent mixing in cities and a nocturnal moisture surplus due to continued evapotranspiration, more anthropogenic moisture sources, and fewer surfaces for condensation. In addition, some cities have shown a moisture deficit in specific months and a surplus in other months. The methods used to measure or derive humidity-related variables vary strongly between the studies. The comparableness is limited among the observational studies as well as to this regional climate model data driven research. Regional climate models are not yet able to represent the complex fine-scale daily humidity cycles described by observational studies. Nevertheless, RCMs are the best tool currently available to understand urban-rural moisture contrasts under climate change during the twenty-first century. As this is one of the first climate model output data studies considering humidity changes under future climate change conditions, further research and comparative studies are needed to gain an improved understanding of commonalities and differences between cities as well as to assess the main generic conclusions. 
To our knowledge, this is the first study to derive an increase in the moisture deficit in Berlin compared to its surroundings under climate change conditions throughout the twenty-first century. In line with other studies that have defined the UDI [31,32], it could be concluded that Berlin shows an increasing urban dry island effect under climate change. Additionally, underpinning the findings of the UDI, an increasing UHI was detected in Berlin under climate change conditions throughout the century. An in-depth process understanding study is needed to identify which parameters lead to these results, e.g., evaporation, radiation, and cloudiness, etc. This could further enhance our knowledge of urban-rural interactions under climate change. Additionally, the mean change in the UDI throughout the century could imply a change in extremes, variability, or compound events. These are all interesting topics for further research.

The described UHI for Berlin should be considered with caution. The temperature difference between Berlin and its surroundings for the diurnal cycle, particularly at nighttime, is not represented adequately by the models. Daniel at al. [10] have also found that the nighttime temperature differences between the city and rural areas are underestimated using an RCM with a 'bulk' approach for the city of Paris as well as other urban areas in France. Sophisticated urban schemes would improve the diurnal temperature difference according to Daniel et al. [10]. Further research and incorporation of sophisticated urban schemes in RCMs are required to address the inadequate representation of the UHI by regional climate models. The misrepresentation of the diurnal cycle temperature difference between Berlin and its surroundings implies that no comprehensive conclusions for the daily temperature cycle can be worked out from this research. The models simulate the timing of the temperature difference inadequately on a sub-daily scale. The models capture the mean daily heat budget and urban-rural temperature contrast. The mean climate change trend results could therefore give a plausible indication for the future for temperature and humidity variables. Prior studies have identified a connection between the UHI effect and humidity fluctuations in urban areas (e.g., $[21,29,30]$ ). As described previously, the models would be expected to simulate the difference in minimum temperature larger between Berlin and its surroundings, and vice versa for maximum temperature. Based hereupon, the maximum temperature as well as the simulated maximum temperature difference could be overestimated. Higher temperatures lead to an increase in saturated water vapor pressure and therefore decreased relative humidity (following Equation (1)). Due to overestimation of the daytime maximum temperature difference by the models, Berlin might be less dry compared to its surroundings than the models present currently.

Climate models are subject to uncertainties, though it is commonly conceived that multi-model ensemble studies result in a more accurate representation of possible futures than those using one single model, reducing the expected uncertainty of the outcomes of this study [73]. The results of the MWW test show that the driving GCM influences RCM outcomes for urban-rural contrasts of relative humidity. Further research would be favorable to further improve our understanding of this topic. Taking this into consideration, the results of this research should be treated with caution and only provide an indication of a possible future change of humidity for Berlin compared to its surroundings.

Running the EURO-CORDEX coordinated simulations with sophisticated urban schemes could potentially change and profoundly improve the outcomes of this type of research, in particular with respect to the daily temperature cycle [10]. Furthermore, it would be of high interest to explore whether the climate change signal for relative humidity would change under state-of-the-art convection permitting models to understand whether simulations on higher spatial resolutions would result in an improved representation of climate change impacts in urban areas.

It would also be important to explore the usability of the findings, particularly with respect to relative humidity for different city sectors and to seek an improved understanding of how to tailor information in a useful manner for urban decision makers. 


\section{Conclusions}

Humidity changes under climate change conditions are poorly understood in urban areas. Changes in humidity can alter living conditions for city inhabitants and an increasing need therefore exists to enhance our knowledge. However, many urban models and climate models are currently either not scale compliant for cities and offer only a limited set of climatological parameters, or do not simulate urban-rural interactions. This work aimed to improve understanding of the change in moisture and temperature variables under climate change, ultimately to be able to equip urban decision makers with science-based information to adapt to projected humidity changes. EURO-CORDEX regional climate model simulations $\left(0.11^{\circ}\right)$ were analyzed for RCP 8.5 with a focus on relative and specific humidity, as well as temperature variables, throughout the century for Berlin and its surroundings.

The main results show that Berlin is getting drier and is facing a larger temperature increase than its surroundings towards the end of the century under climate change conditions. This is particularly profound in summer, with a mean decadal RH decrease of up to 6\% when comparing 1970-1979 with 2090-2099. Berlin is warming more strongly than its surroundings throughout the entire year, i.e., by $\sim 2^{\circ} \mathrm{C}$ when comparing 1971-2000 with 2070-2099. This study discloses for the first time that the EURO-CORDEX multi-model ensemble is able to capture a humidity difference between Berlin and its surroundings, as well as quantifies the respective climate change urban-rural trends throughout the century. Additionally, the study also shows limitations of the RCMs in this respect. For the historic climate period (1970-2017), the outcomes are similar between the model simulations and observations, though there is a slight overestimation of the water vapor deficit in Berlin by the models. A comparison between the REMO model and observations for the historic diurnal temperature cycle shows that REMO simulates a larger UHI during daytime. The RCMs are unable to represent the expected dominant nighttime urban heat island effect adequately. This might have profound influence on overall RCM results for urban areas and needs to be addressed in the future. The running mean over 30 years shows a divergence throughout the twenty-first century for relative humidity between Berlin and its surroundings, with Berlin getting drier over time, which was validated by the Mann-Kendall test. The Mann-Whitney-Wilcoxon test for relative humidity indicates a robust climate change signal in Berlin. Berlin is drier and warmer for all months, with the largest difference compared to its surroundings in the summer. Also, the change in humidity in 2070-2099 compared to 1971-2000 is largest in the summer months.

In summary, this study shows for the first time an increasing urban dry island under climate change conditions throughout the twenty-first century in Berlin.

Author Contributions: Conceptualization, G.S.L., D.R., and D.J.; data curation, G.S.L.; formal analysis, G.S.L.; investigation, G.S.L.; methodology, G.S.L.; project administration, G.S.L.; resources, G.S.L.; software, G.S.L.; supervision, D.R. and D.J.; validation, G.S.L.; visualization, G.S.L.; writing—original draft, G.S.L.; writing一review and editing, G.S.L., D.R., and D.J.

Funding: This research received no external funding. The research was funded by the Climate Service Center Germany (GERICS), Helmholtz-Zentrum Geesthacht (HZG) as a part of G.S.L's doctorate.

Acknowledgments: We wish to acknowledge the World Climate Research Programme's Working Group on Regional Climate and the Working Group on Coupled Modeling, the former coordinating body of CORDEX and the panel responsible for CMIP5. We also thank the climate modeling groups for producing and making available their model output. The authors acknowledge the contributing climate modeling centers for the EURO-CORDEX simulations and for making them freely available. We also acknowledge the Earth System Grid Federation infrastructure, an international effort led by the US Department of Energy's Program for Climate Model Diagnosis and Intercomparison, the European Network for Earth System Modeling, and other partners in the Global Organization for Earth System Science Portals (GO-ESSP). In addition, we acknowledge the contributions of the EURO-CORDEX regional climate modeling groups to the survey on urban representation in RCMs used for EURO-CORDEX $0.11^{\circ}$ simulations. We thank R. Parks for proofreading the manuscript and providing suggestions to improve readability. We wish to acknowledge the reviewers for their valuable feedback that greatly improved the manuscript.

Conflicts of Interest: The authors declare no conflict of interest. 


\section{Appendix A}

Table A1. EURO-CORDEX community survey outcomes on urban representation in RCMs used for EURO-CORDEX $0.11^{\circ}$ simulations.

\begin{tabular}{|c|c|c|c|}
\hline Name of Institution & $\begin{array}{c}\text { Model Versions Used } \\
\text { for EURO-CORDEX } \\
\text { Simulations on ESGF }\end{array}$ & $\begin{array}{c}\text { Urban } \\
\text { Representation }\end{array}$ & Description and References \\
\hline $\begin{array}{l}\text { Climate Service } \\
\text { Center Germany } \\
\text { (GERICS) }\end{array}$ & REMO2009 & Bulk & $\begin{array}{l}\text { Land-use type urban. Urban is treated as } \\
\text { rock surfaces. Roughness length and } \\
\text { albedo adjusted. No field capacity, nor } \\
\text { vegetation. Fractional approach }[49,50] \text {. }\end{array}$ \\
\hline $\begin{array}{c}\text { Swedish } \\
\text { Meteorological and } \\
\text { Hydrological } \\
\text { Institute (SMHI) }\end{array}$ & RCA4 & Bulk & $\begin{array}{l}\text { Land-use physiography is based on } \\
\text { ECOCLIMAP land-surface database [45]. } \\
\text { RCA4 includes no further direct reference } \\
\text { to urban parameterizations [48]. }\end{array}$ \\
\hline $\begin{array}{l}\text { Royal Netherlands } \\
\text { Meteorological } \\
\text { Institute (KNMI) }\end{array}$ & RACMO22E & Bulk & $\begin{array}{l}\text { RACMO22E is based on CY31r1 Urban } \\
\text { fraction based on ECOCLIMAP } \\
\text { land-surface database [45]. Dominant tile } \\
\text { approach. Roughness lengths and surface } \\
\text { interactions adjusted for urban land } \\
\text { cover [46]. }\end{array}$ \\
\hline $\begin{array}{c}\text { Danish } \\
\text { Meteorological } \\
\text { Institute (DMI) }\end{array}$ & HIRHAM5 & Bulk & $\begin{array}{l}\text { HIRHAM5 [51] includes ECHAM4 [52]. } \\
\text { Urban represented through adjusted } \\
\text { constant surface parameters. }\end{array}$ \\
\hline $\begin{array}{l}\text { Institute Pierre } \\
\text { Simon } \\
\text { Laplache(IPSL) }\end{array}$ & $\begin{array}{l}\text { CM5A-MR- } \\
\text { WRF331F }\end{array}$ & Bulk & $\begin{array}{l}\text { The vegetation/soil parameters are adjusted } \\
\text { for urban land surface type (e.g., albedo and } \\
\text { roughness length) [66] in NOAH-LSM [47]. } \\
\text { Urban Canopy model available but not } \\
\text { turned on for EURO-CORDEX simulations. }\end{array}$ \\
\hline $\begin{array}{l}\text { Climate Limit-Area } \\
\text { Modeling } \\
\text { Community (CLM) }\end{array}$ & COSMO-CLM & Bulk & $\begin{array}{l}\text { Surface land cover type urban. } \\
\text { Each sub-grid land cover type is a separate } \\
\text { column for energy and water } \\
\text { calculations [44]. TERRA-LM is used for } \\
\text { EURO-CORDEX simulations. }\end{array}$ \\
\hline
\end{tabular}

Table A2. Outcomes of the Mann-Kendall (MK) test, Levene test, and Mann-Whitney-Wilcoxon (MWW) test for relative humidity for Berlin and its surroundings.

\begin{tabular}{|c|c|c|c|c|c|c|c|}
\hline & \multirow[b]{2}{*}{$\begin{array}{l}\text { Model Combination } \\
\text { (GCM_RCM) }\end{array}$} & \multicolumn{2}{|l|}{ MK Test } & \multicolumn{2}{|c|}{ Levene Test } & \multicolumn{2}{|c|}{ MWW Test } \\
\hline & & Direction & $p$ Value & $t$ Value & $p$ Value & $t$ Value & $p$ Value \\
\hline \multirow{9}{*}{ Berlin } & EC-EARTH_RCA4 & Decreasing & $2.58 \times 10^{-06}$ & 0.0003 & 0.9855 & 226 & 0.0002 \\
\hline & EC-EARTH_RACMO22E & Decreasing & $3.33 \times 10^{-15}$ & 0.2236 & 0.6380 & 156 & $2.54 \times 10^{-06}$ \\
\hline & EC-EARTH_HIRHAM5 & No trend & 0.8689 & 0.3136 & 0.5775 & 446 & 0.3161 \\
\hline & CM5A-MR_WRF331F & No trend & 0.5196 & 16.184 & 0.2082 & 405 & 0.1455 \\
\hline & CM5A-MR_RCA4 & Decreasing & $3.97 \times 10^{-11}$ & 61.218 & 0.0162 & 159 & $3.10 \times 10^{-06}$ \\
\hline & HadGEM2_RCA4 & Decreasing & $5.64 \times 10^{-07}$ & 21.851 & 0.1446 & 231 & 0.0002 \\
\hline & HadGEM2_RACMO22E & Decreasing & 0.0000 & 0.1718 & 0.6800 & 40 & $2.92 \times 10^{-10}$ \\
\hline & MPI-ESM-LR_REMO2009(r1) & Decreasing & $2.22 \times 10^{-16}$ & 57.208 & 0.0199 & 80 & $8.94 \times 10^{-09}$ \\
\hline & MPI-ESM-LR_REMO2009(r2) & Decreasing & $4.88 \times 10^{-14}$ & 24.869 & 0.1201 & 102 & $5.14 \times 10^{-08}$ \\
\hline \multirow{9}{*}{ Surroundings } & EC-EARTH_RCA4 & No trend & 0.3124 & 91.139 & 0.0037 & 447 & 0.3211 \\
\hline & EC-EARTH_RACMO22E & No trend & 0.7353 & 29.544 & 0.0908 & 474 & 0.4663 \\
\hline & EC-EARTH_HIRHAM5 & Increasing & 0.0329 & 0.4255 & 0.5167 & 372 & 0.0642 \\
\hline & CM5A-MR_WRF331F & Increasing & 0.0061 & 0.6487 & 0.4238 & 331 & 0.0180 \\
\hline & CM5A-MR_RCA4 & Increasing & 0.0001 & 0.3001 & 0.5858 & 227 & 0.0002 \\
\hline & HadGEM2_RCA4 & Increasing & 0.0225 & 0.0003 & 0.9870 & 364 & 0.0512 \\
\hline & HadGEM2_RĀCMO22E & No trend & 0.7967 & 0.0299 & 0.8632 & 460 & 0.3891 \\
\hline & MPI-ESM-LR_REMO2009(r1) & No trend & 0.4589 & 0.0414 & 0.8395 & 452 & 0.3467 \\
\hline & MPI-ESM-LR_REMO2009(r2) & No trend & 0.8154 & 0.0099 & 0.9212 & 462 & 0.4000 \\
\hline
\end{tabular}



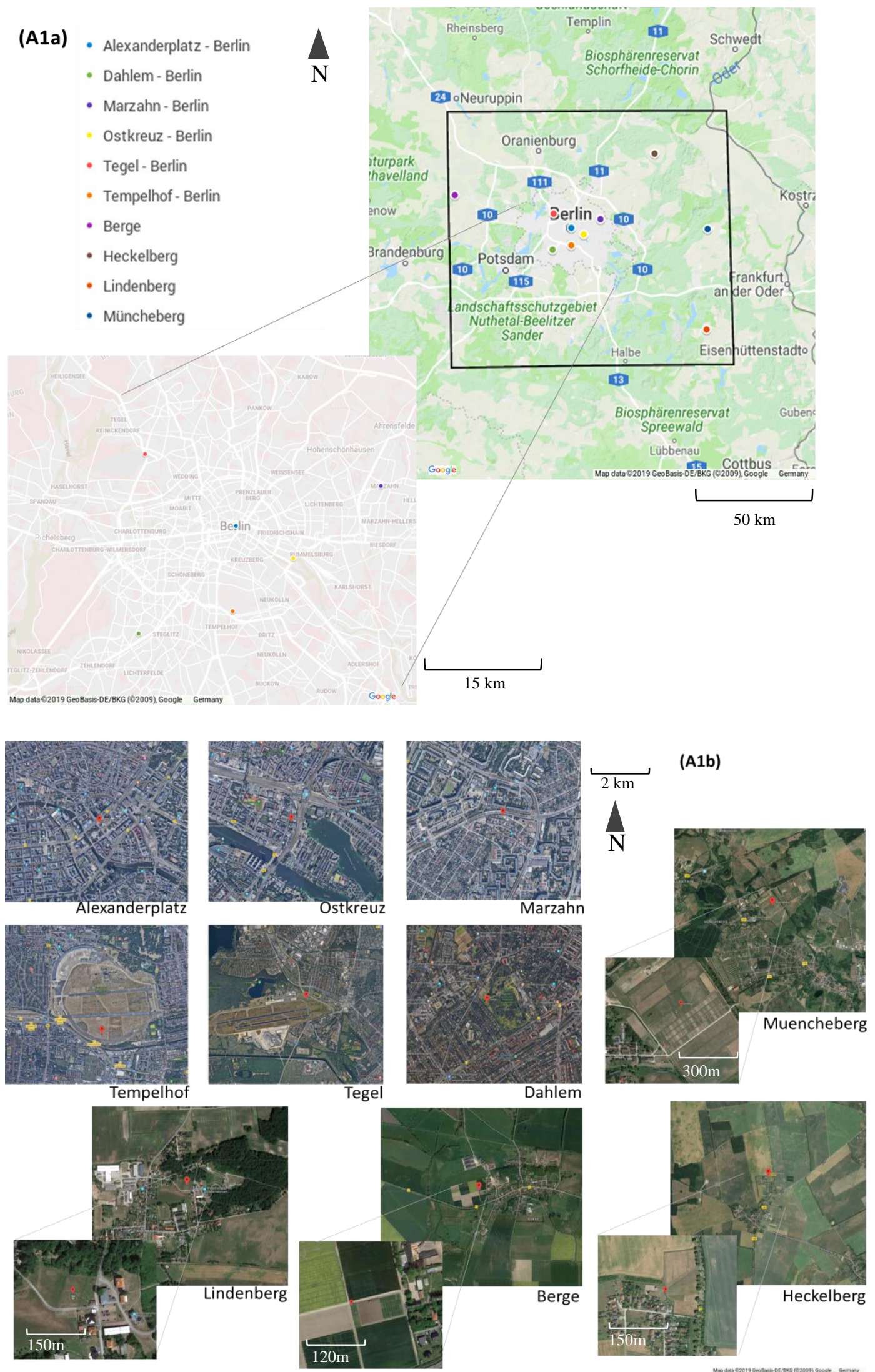

Figure A1. Locations of observational stations (a) and their surrounding environments (b). Map data from 2019 GeoBasis DE/BKG, Google, Germany. 
Table A3. Standard deviation for each model combination and for the investigated variables calculated over the annual mean for the period 1970-2016.

\begin{tabular}{ccccccc}
\hline & & & Variables \\
\hline & $\begin{array}{c}\text { Model Combination } \\
\text { (GCM_RCM) }\end{array}$ & RH (\%) & SH (-) & Tas $\left({ }^{\circ} \mathbf{C}\right)$ & Tasmax $\left({ }^{\circ} \mathbf{C}\right)$ & Tasmin $\left({ }^{\circ} \mathbf{C}\right)$ \\
\hline EC-EARTH_RCA4 & 0.80 & 0.00017 & 0.60 & 0.59 & 0.62 \\
EC-EARTH_RACMO22E & 0.76 & 0.00017 & 0.62 & 0.60 & 0.64 \\
EC-EARTH_HIRHAM5 & 0.46 & 0.00013 & 0.48 & 0.46 & 0.52 \\
CM5A-MR_WRF331F & 0.55 & 0.00022 & 0.85 & 0.83 & 0.88 \\
CM5A-MR_RCA4 & 0.58 & 0.00021 & 0.79 & 0.80 & 0.78 \\
& HadGEM2_RCA4 & 0.61 & 0.00019 & 0.71 & 0.71 & 0.71 \\
& HadGEM2_RACMO22E & 0.71 & 0.00021 & 0.78 & 0.77 & 0.79 \\
& MPI-ESM-LR_REMO2009(r1) & 0.72 & 0.00014 & 0.47 & 0.47 & 0.49 \\
& MPI-ESM-LR_REMO2009(r2) & 0.68 & 0.00014 & 0.52 & 0.54 & 0.54 \\
\hline EC-EARTH_RCA4 & 1.83 & 0.00026 & 0.75 & 0.79 & 0.78 \\
& EC-EARTH_RACMO22E & 1.64 & 0.00024 & 0.82 & 0.83 & 0.80 \\
EC-EARTH_HIRHAM5 & 1.51 & 0.00021 & 0.79 & 0.80 & 0.81 \\
CM5A-MR_WRF331F & 2.14 & 0.00029 & 1.34 & 1.35 & 1.38 \\
CM5A-MR_RCA4 & 1.56 & 0.00030 & 1.09 & 1.20 & 1.04 \\
HadGEM2_RCA4 & 2.39 & 0.00030 & 0.99 & 1.14 & 0.90 \\
& HadGEM2_RACMO22E & 1.98 & 0.00025 & 1.06 & 1.08 & 1.06 \\
& MPI-ESM-LR_REMO2009(r1) & 1.88 & 0.00026 & 0.71 & 0.77 & 0.72 \\
MPI-ESM-LR_REMO2009(r2) & 2.11 & 0.00023 & 0.82 & 0.87 & 0.86 \\
\hline
\end{tabular}
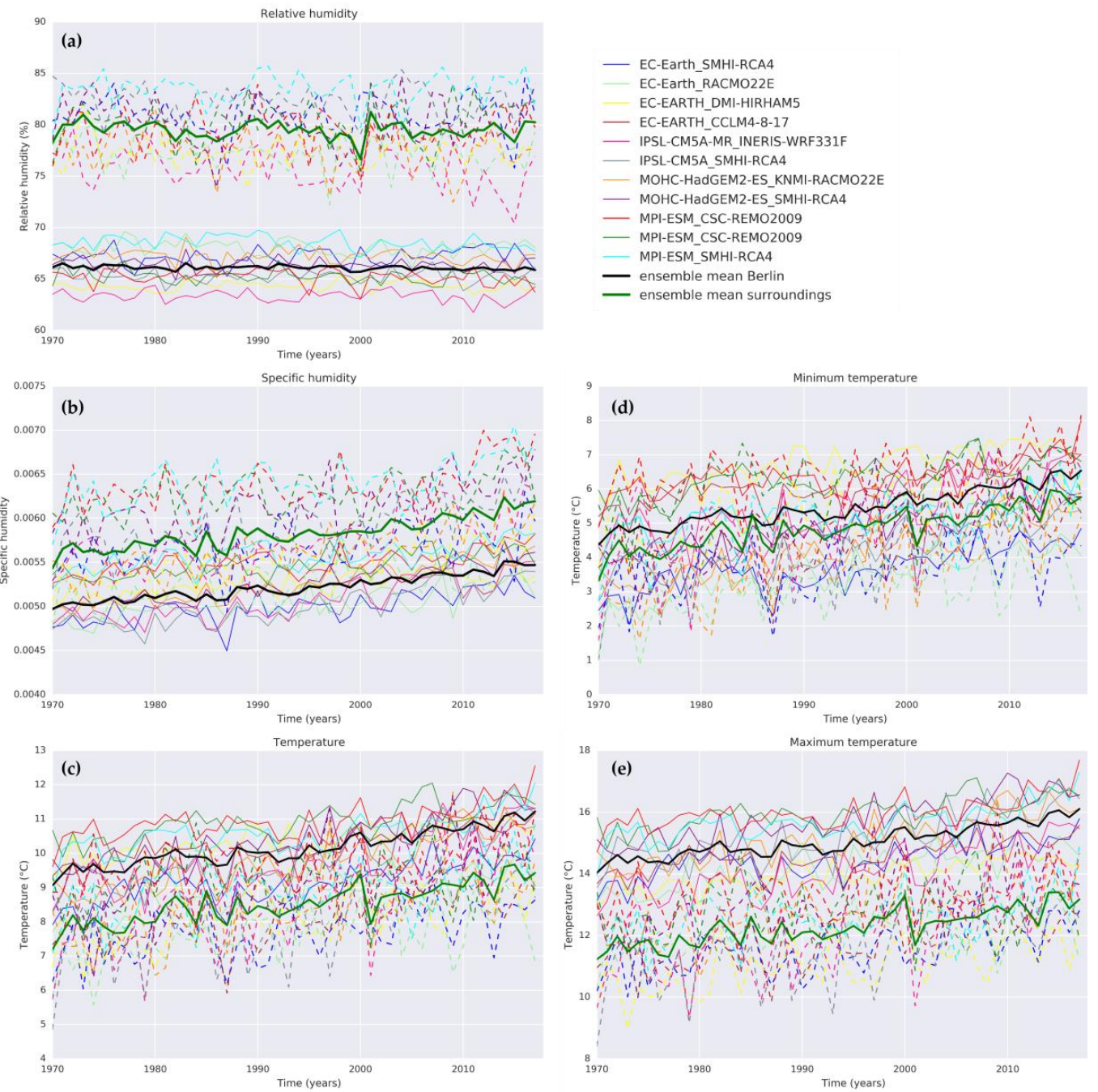

Figure A2. Yearly mean for each model of the EURO-CORDEX multi-model ensemble compared to the multi-model mean for 1970-2017. The variables presented are (a) relative humidity, (b) specific humidity, (c) temperature, (d) minimum temperature, and (e) maximum temperature. 


\section{References}

1. UN-HABITAT. Urbanization and Development: Emerging Futures World Cities Report 2016; United Nations Human Settlements Programme (UN-Habitat): Nairobi, Kenya, 2016. [CrossRef]

2. ONU. New Urban Agenda. In Health Visit; United Nations Habitat III: Geneva, Switzerland, 2017; ISBN 978-92-1-132757-1.

3. Rosenzweig, C.; Solecki, W.; Romero-Lankao, P.; Mehrotra, S.; Dhakal, S.; Bowman, T.; Ibrahim, S.A. Climate Change and Cities: Second Assessment Report of the Urban Climate Change Research Network. In Climate Change and Cities; Cambridge University Press: Cambridge, UK, 2018. [CrossRef]

4. Baklanov, A.; Grimmond, C.S.B.; Carlson, D.; Terblanche, D.; Tang, X.; Bouchet, V.; Lee, B.; Langendijk, G.; Kolli, R.K.; Hovsepyan, A. From Urban Meteorology, Climate and Environment Research to Integrated City Services. Urban Clim. 2018, 23, 330-341. [CrossRef]

5. $\quad$ Grimmond, C.S.B.; Roth, M.; Oke, T.R.; Au, Y.C.; Best, M.; Betts, R.; Carmichael, G.; Cleugh, H.; Dabberdt, W.; Emmanuel, R.; et al. Climate and More Sustainable Cities: Climate Information for Improved Planning and Management of Cities (Producers/Capabilities Perspective). Procedia Environ. Sci. 2010, 1, $247-274$. [CrossRef]

6. Bai, X.; Dawson, R.J.; Ürge-Vorsatz, D.; Delgado, G.C.; Salisu Barau, A.; Dhakal, S.; Dodman, D.; Leonardsen, L.; Masson-Delmotte, V.; Roberts, D.C.; et al. Six Research Priorities for Cities and Climate Change. Nature 2018, 555, 23-25. [CrossRef] [PubMed]

7. Jacob, D.; Petersen, J.; Eggert, B.; Alias, A.; Christensen, O.B.; Bouwer, L.M.; Braun, A.; Colette, A.; Déqué, M.; Georgievski, G.; et al. EURO-CORDEX: New High-Resolution Climate Change Projections for European Impact Research. Reg. Environ. Chang. 2014, 14, 563-578. [CrossRef]

8. Giorgi, F.; Gutowski, W.J. Regional Dynamical Downscaling and the CORDEX Initiative. Annu. Rev. Environ. Resour. 2015, 40, 467-490. [CrossRef]

9. Gutowski, J.W.; Giorgi, F.; Timbal, B.; Frigon, A.; Jacob, D.; Kang, H.S.; Raghavan, K.; Lee, B.; Lennard, C.; Nikulin, G.; et al. WCRP COordinated Regional Downscaling EXperiment (CORDEX): A Diagnostic MIP for CMIP6. Geosci. Model Dev. 2016, 9, 4087-4095. [CrossRef]

10. Daniel, M.; Lemonsu, A.; Déqué, M.; Somot, S.; Alias, A.; Masson, V. Benefits of Explicit Urban Parameterization in Regional Climate Modeling to Study Climate and City Interactions. In Climate Dynamics; Springer: Berlin, Germany, 2018; pp. 1-20. [CrossRef]

11. Chen, F.; Kusaka, H.; Bornstein, R.; Ching, J.; Grimmond, C.S.B.; Grossman-Clarke, S.; Loridan, T.; Manning, K.W.; Martilli, A.; Miao, S.; et al. The Integrated WRF/Urban Modelling System: Development, Evaluation, and Applications to Urban Environmental Problems. Int. J. Climatol. 2011, 31, 273-288. [CrossRef]

12. Trusilova, K.; Schubert, S.; Wouters, H.; Früh, B.; Grossman-Clarke, S.; Demuzere, M.; Becker, P. The Urban Land Use in the COSMO-CLM Model: A Comparison of Three Parameterizations for Berlin. Meteorol. Z. 2016, 25, 231-244. [CrossRef]

13. Best, M.J.; Grimmond, C.S.B. Analysis of the Seasonal Cycle Within the First International Urban Land-Surface Model Comparison. Bound. Layer Meteorol. 2013, 146, 421-446. [CrossRef]

14. Best, M.J.; Grimmond, C.S.B. Investigation of the Impact of Anthropogenic Heat Flux within an Urban Land Surface Model and PILPS-Urban. Theor. Appl. Climatol. 2016, 126, 51-60. [CrossRef]

15. Masson, V. Urban Surface Modeling and the Meso-Scale Impact of Cities. Theor. Appl. Climatol. 2006, 84, 35-45. [CrossRef]

16. Karlický, J.; Huszár, P.; Halenka, T.; Belda, M.; Žák, M.; Pišoft, P.; Mikšovský, J. Multi-Model Comparison of Urban Heat Island Modelling Approaches. Atmos. Chem. Phys. 2018, 18, 10655-10674. [CrossRef]

17. De Ridder, K.; Lauwaet, D.; Maiheu, B. UrbClim-A Fast Urban Boundary Layer Climate Model. Urban Clim. 2015, 12, 21-48. [CrossRef]

18. Huszar, P.; Halenka, T.; Belda, M.; Zak, M.; Sindelarova, K.; Miksovsky, J. Regional Climate Model Assessment of the Urban Land-Surface Forcing over Central Europe. Atmos. Chem. Phys. 2014, 14, 12393-12413. [CrossRef]

19. Lauwaet, D.; Hooyberghs, H.; Maiheu, B.; Lefebvre, W.; Driesen, G.; Van Looy, S.; De Ridder, K. Detailed Urban Heat Island Projections for Cities Worldwide: Dynamical Downscaling CMIP5 Global Climate Models. Climate 2015, 3, 391-415. [CrossRef] 
20. Wiesner, S.; Bechtel, B.; Fischereit, J.; Gruetzun, V.; Hoffmann, P.; Leitl, B.; Rechid, D.; Schlünzen, K.; Thomsen, S. Is It Possible to Distinguish Global and Regional Climate Change from Urban Land Cover Induced Signals? A Mid-Latitude City Example. Urban Sci. 2018, 2, 12. [CrossRef]

21. Robaa, S.M. Urban-Suburban/Rural Differences over Greater Cairo, Egypt. Atmosfera 2003, 16, $157-171$.

22. Ackerman, B. Climatology of Chicago Area Urban-Rural Differences in Humidity. J. Clim. Appl. Meteorol. 2002, 26, 427-430. [CrossRef]

23. Tapper, N.J. Urban Influences on Boundary Layer Temperature and Humidity: Results from Christchurch, New Zealand. Atmos. Environ. Part B Urban Atmos. 1990, 24, 19-27. [CrossRef]

24. Hage, K.D. Urban-Rural Humidity Differences. J. Appl. Meteorol. 1975, 14, 1277-1283. [CrossRef]

25. Fortuniak, K.; Kłysik, K.; Wibig, J. Urban—Rural Contrasts of Meteorological Parameters in Łódź. Theor. Appl. Climatol. 2006, 84, 91-101. [CrossRef]

26. Jåuregui, E.; Tejeda, A. Urban-Rural Humidity Contrasts in Mexico City. Int. J. Climatol. 1997, 17, $187-196$. [CrossRef]

27. Unkašević, M.; Jovanović, O.; Popović, T. Urban-Suburban/Rural Vapour Pressure and Relative Humidity Differences at Fixed Hours over the Area of Belgrade City. Theor. Appl. Climatol. 2001, 68, 67-73. [CrossRef]

28. Kuttler, W.; Weber, S.; Schonnefeld, J.; Hesselschwerdt, A. Urban/Rural Atmospheric Water Vapour Pressure Differences and Urban Moisture Excess in Krefeld, Germany. Int. J. Climatol. 2007, 27, 2005-2015. [CrossRef]

29. Lee, D.O. Urban-Rural Humidity Differences in London. Int. J. Climatol. 1991, 11, 577-582. [CrossRef]

30. Unger, J. Urban-Rural Air Humidity Differences in Szeged, Hungary. Int. J. Climatol. 1999, 19, $1509-1515$. [CrossRef]

31. Lokoshchenko, M.A. Urban Heat Island and Urban Dry Island in Moscow and Their Centennial Changes. J. Appl. Meteorol. Climatol. 2017, 56, 2729-2745. [CrossRef]

32. Moriwaki, R.; Watanabe, K.; Morimoto, K. Urban dry island phenomenon and its impact on cloud base level. J. JSCE 2013, 1, 521-529. [CrossRef]

33. Coccolo, S.; Kämpf, J.; Scartezzini, J.L.; Pearlmutter, D. Outdoor Human Comfort and Thermal Stress: A Comprehensive Review on Models and Standards. In Urban Climate; Elsevier B.V.: Amsterdam, The Netherlands, 2016; pp. 33-57. [CrossRef]

34. Chiabai, A.; Quiroga, S.; Martinez-Juarez, P.; Higgins, S.; Taylor, T. The Nexus between Climate Change, Ecosystem Services and Human Health: Towards a Conceptual Framework. Sci. Total Environ. 2018, 635, 1191-1204. [CrossRef]

35. Rohat, G.; Flacke, J.; Dosio, A.; Dao, H.; van Maarseveen, M. Projections of Human Exposure to Dangerous Heat in African Cities Under Multiple Socioeconomic and Climate Scenarios. Earth's Futur 2019, 7, 528-546. [CrossRef]

36. Abuku, M.; Janssen, H.; Roels, S. Impact of Wind-Driven Rain on Historic Brick Wall Buildings in a Moderately Cold and Humid Climate: Numerical Analyses of Mould Growth Risk, Indoor Climate and Energy Consumption. Energy Build. 2009, 41, 101-110. [CrossRef]

37. Blocken, B.; Carmeliet, J. A Review of Wind-Driven Rain Research in Building Science. J. Wind Eng. Ind. Aerodyn. 2004, 92, 1079-1130. [CrossRef]

38. Elmqvist, T.; Goodness, J.; Marcotullio, P.J.; Parnell, S.; Sendstad, M.; Wilkinson, C.; Fragkias, M.; Güneralp, B.; McDonald, R.I.; Schewenius, M.; et al. Urbanization, Biodiversity and Ecosystem Services: Challenges and Opportunities: A Global Assessment; Springer: Heidelberg, Germany, 2013. [CrossRef]

39. Lahr, E.C.; Dunn, R.R.; Frank, S.D. Getting Ahead of the Curve: Cities as Surrogates for Global Change. Proc. R. Soc. B Biol. Sci. 2018, 285, 20180643. [CrossRef] [PubMed]

40. Amt für Statistik Berlin-Brandenburg. Statistiken Berlin und Brandenburg. Available online: https://www.statistik-berlin-brandenburg.de/statistiken/Inhalt-Statistiken.asp (accessed on 26 July 2019).

41. Statistiken Berlin und Brandenburg Flaechenutzung. Available online: https://www.statistik-berlinbrandenburg.de/BasisZeitreiheGrafik/Bas-Flaechennutzung.asp?Ptyp=300\&Sageb=33000\&creg=BBB\& anzwer=6 (accessed on 10 June 2019).

42. EEA. The Revised and Supplemented Corine Land Cover Nomenclature, EEA Technical Report No. 40; European Environment Agency: Copehagen, Denmark, 2000. 
43. German Climate Computing Centre (DKRZ); Earth System Grid Federation (ESGF); World Climate Research programme (WCRP); Coordinated Regional Climate Downscaling Experiment (CORDEX); G.C.C. Earth System Grid Federation WCRP CORDEX Data Node. Available online: https://esgf-data.dkrz.de/search/ cordex-dkrz/ (accessed on 20 November 2018).

44. Rockel, B.; Will, A.; Hense, A. The Regional Climate Model COSMO-CLM (CCLM). Meteorol. Z. 2008, 17, 347-348. [CrossRef]

45. Masson, V.; Champeaux, J.L.; Chauvin, F.; Meriguet, C.; Lacaze, R. A Global Database of Land Surface Parameters at 1-Km Resolution in Meteorological and Climate Models. J. Clim. 2003, 16, 1261-1282. [CrossRef]

46. Van Meijgaard, E.; Van Ulft, L.H.; Van De Berg, W.J.; Bosveld, F.C.; Van Den Hurk, B.J.J.M.; Lenderink, G.; Siebesma, A.P. The KNMI Regional Atmospheric Climate Model RACMO; Version 2.1; Koninklijk Nederlands Meteorologisch Instituut (KNMI): de Bilt, The Netherlands, 2008.

47. Niu, G.Y.; Yang, Z.L.; Mitchell, K.E.; Chen, F.; Ek, M.B.; Barlage, M.; Kumar, A.; Manning, K.; Niyogi, D.; Rosero, E.; et al. The Community Noah Land Surface Model with Multiparameterization Options (Noah-MP): 1. Model Description and Evaluation with Local-Scale Measurements. J. Geophys. Res. Atmos. $2011,116$. [CrossRef]

48. Samuelsson, P.; Jones, C.G.; Willén, U.; Ullerstig, A.; Gollvik, S.; Hansson, U.; Jansson, C.; Kjellström, E.; Nikulin, G.; Wyser, K. The Rossby Centre Regional Climate Model RCA3: Model Description and Performance. Tellus Ser. A Dyn. Meteorol. Oceanogr. 2011, 63, 4-23. [CrossRef]

49. Jacob, D.; Elizalde, A.; Haensler, A.; Hagemann, S.; Kumar, P.; Podzun, R.; Rechid, D.; Remedio, A.R.; Saeed, F.; Sieck, K.; et al. Assessing the Transferability of the Regional Climate Model REMO to Different Coordinated Regional Climate Downscaling Experiment (CORDEX) Regions. Atmosphere (Basel) 2012, 3, 181-199. [CrossRef]

50. Jacob, D.; Podzun, R. Sensitivity Studies with the Regional Climate Model REMO. Meteorol. Atmos. Phys. 1997, 63, 119-129. [CrossRef]

51. Christensen, O.B.; Drews, M.; Christensen, J.H.; Dethloff, K.; Ketelsen, K.; Hebestadt, I.; Rinke, A. The HIRHAM Regional Climate Model Version 5 (Beta), Technical Report 06-17; Danish Climate Center (DMI): Copenhagen, Denmark, 2007.

52. Roeckner, E.; Arpe, K.; Bengtsson, L.; Christoph, M.; Claussen, M.; Dümenil, L.; Esch, M.; Giorgetta, M.A.; Schlese, U.; Schulzweida, U. The Atmospheric General Circulation Model Echam-4: Model Description and Simulation of Present-Day Climate; Max-Planck-Institut für Meteorologie: Hamburg, Germany, 1996.

53. Deutsche Wetter Dienst (DWD). German Weather Service, Climate Data Center (CDC). Available online: https://cdc.dwd.de/portal/ (accessed on 25 January 2019).

54. DWD Climate Data Center (CDC): Annual Mean of Station Observations of Relative Humidity at $2 \mathrm{~m}$ above Ground in \%, Version V18.3. Available online: https://cdc.dwd.de/portal/ (accessed on 20 May 2019).

55. DWD Climate Data Center (CDC): Annual Mean of Station Observations of Daily Air Temperature Minimum at $2 \mathrm{~m}$ above Ground in ${ }^{\circ} \mathrm{C}$ (for TasMin), Version V18.3. Available online: https://cdc.dwd.de/portal/ (accessed on 20 May 2019).

56. DWD Climate Data Center (CDC): Annual Mean of Station Observations of Daily Air Temperature Maximum at $2 \mathrm{~m}$ above Ground in ${ }^{\circ} \mathrm{C}$ (for TasMax), Version V18.3. Available online: https://cdc.dwd.de/portal/ (accessed on 20 May 2019).

57. DWD Climate Data Center (CDC): Annual Mean of Station Observations of Air Temperature at $2 \mathrm{~m}$ above Ground in ${ }^{\circ} \mathrm{C}$ (for Tas), Version V18.3. Available online: https://cdc.dwd.de/portal/ (accessed on 20 May 2019).

58. Hass, A.L.; Ellis, K.N.; Mason, L.R.; Hathaway, J.M.; Howe, D.A. Heat and Humidity in the City: Neighborhood Heat Index Variability in a Mid-Sized City in the Southeastern United States. Int. J. Environ. Res. Public Health 2016, 13, 117. [CrossRef]

59. van Vuuren, D.P.; Edmonds, J.; Kainuma, M.; Riahi, K.; Thomson, A.; Hibbard, K.; Hurtt, G.C.; Kram, T.; Krey, V.; Lamarque, J.F.; et al. The Representative Concentration Pathways: An Overview. Clim. Chang. 2011, 102, 5. [CrossRef]

60. Hennemuth, B.; Bender, S.; Bülow, K.; Dreier, N.; Keup-Thiel, E.; Krüger, O.; Mudersbach, C.; Radermacher, C.; Schoetter, R. Statistical Methods for the Analysis of Simulated and Observed Climate Data Applied in Projects and Institutions Dealing with Climate Change Impact and Adaptation. CSC Rep. 2013, 13, 1-135.

61. Mann, H.B. Nonparametric Tests Against Trend. Econometrica 1945, 13, 245-259. [CrossRef] 
62. Kendall, M.G. Rank Correlation Methods. By Maurice G. Kendall, M.A. [Pp. Vii + 160. London: Charles Griffin and Co. Ltd., 42 Drury Lane, 1948. 18 S]. J. Inst. Actuar. 1949, 75, 140-141. [CrossRef]

63. Pfeifer, S.; Bülow, K.; Gobiet, A.; Hänsler, A.; Mudelsee, M.; Otto, J.; Rechid, D.; Teichmann, C.; Jacob, D. Robustness of Ensemble Climate Projections Analyzed with Climate Signal Maps: Seasonal and Extreme Precipitation for Germany. Atmosphere (Basel) 2015, 6, 677-698. [CrossRef]

64. Brown, M.B.; Forsythe, A.B. Robust Tests for the Equality of Variances. J. Am. Stat. Assoc. 1974, 69, $364-367$. [CrossRef]

65. DWD Climate Data Center (CDC): Hourly Station Observations of Air Temperature at $2 \mathrm{~m}$ above Ground in ${ }^{\circ}$ C, Version V18.3. Available online: https://cdc.dwd.de/portal/ (accessed on 10 April 2019).

66. Skamarock, W.C.; Klemp, J.B.; Dudhia, J.; Gill, D.O.; Barker, D.M.; Duda, M.G.; Huang, X.-Y.; Wang, W.; Powers, J.G. A Description of the Advanced Research WRF; Version 3; National Center for Atmospheric Research: Boulder, CO, USA, 2008.

67. Li, H.; Zhou, Y.; Li, X.; Meng, L.; Wang, X.; Wu, S.; Sodoudi, S. A New Method to Quantify Surface Urban Heat Island Intensity. Sci. Total Environ. 2018, 624, 262-272. [CrossRef]

68. Zhou, B. On The Assessment Of Surface Urban Heat Island: Size, Urban Form, and Seasonality; Institutional Repository of the University of Potsdam: Potsdam, Germany, 2017.

69. Li, H.; Meier, F.; Lee, X.; Chakraborty, T.; Liu, J.; Schaap, M.; Sodoudi, S. Interaction between Urban Heat Island and Urban Pollution Island during Summer in Berlin. Sci. Total Environ. 2018, 636, 818-828. [CrossRef]

70. Wang, L.; Gao, Z.; Miao, S.; Guo, X.; Sun, T.; Liu, M.; Li, D. Contrasting Characteristics of the Surface Energy Balance between the Urban and Rural Areas of Beijing. Adv. Atmos. Sci. 2015, 32, 505-514. [CrossRef]

71. Illston, B.G.; Basara, J.B.; Crawford, K.C. Seasonal to Interannual Variations of Soil Moisture Measured in Oklahoma. Int. J. Climatol. 2004, 24, 1883-1896. [CrossRef]

72. Jänicke, B.; Meier, F.; Fenner, D.; Fehrenbach, U.; Holtmann, A.; Scherer, D. Urban-Rural Differences in near-Surface Air Temperature as Resolved by the Central Europe Refined Analysis (CER): Sensitivity to Planetary Boundary Layer Schemes and Urban Canopy Models. Int. J. Climatol. 2017, 37, 2063-2079. [CrossRef]

73. Christensen, J.H.; Carter, T.R.; Rummukainen, M.; Amanatidis, G. Evaluating the Performance and Utility of Regional Climate Models: The PRUDENCE Project. Clim. Chang. 2007, 81, 1-6. [CrossRef] 